\title{
Dimensões do governo colonial em Moçâmedes e suas conexões com o Brasil: trabalho, negócios e conflitos, $1840-1860^{*}$
}

\author{
Dimensions of colonial government in Moçâmedes and its \\ connections with Brazil: work, business and conflicts, 1840-1860
}

\section{Maria Luiza Ferreira Oliveira**}

Resumo: Este artigo mapeia conexões de homens, saberes e negócios entre Portugal, Angola e o Brasil nos anos de 1840 a 1860. Investigo a circulação dos saberes de produção de commodities, assim como pretendo esmiuçar as práticas da administração colonial, especialmente sobre as formas de arregimentação do trabalho (especializado e braçal) nesse momento dos cruzadores e dos tratados antitráfico. Busco ressaltar as tensões, embates e uma persistente resistência que operava de diversas formas, seja na recusa ao trabalho, na fuga, na luta institucional ou na guerra. O artigo tem quatro partes: na primeira, examino a circulação de ideias sobre a colonização militar nesse período; em seguida, procuro observar, no estabelecimento de Moçâmedes, as suas conexões com o Brasil; em uma terceira parte, estudo a fundamental presença dos trabalhadores libertos e escravos; e, por fim, trato das contínuas guerras travadas na região, sobretudo nos últimos anos da década de 1850 . Ao longo do artigo, estão algumas trajetórias reveladoras de percursos atlânticos nos negócios e na administração colonial: indivíduos formados nas lutas políticas dos anos 1820-1830 que assumiam novos (velhos) papéis nos novos (velhos) tempos da colonização.

Palavras-chave: Colonização militar; trabalho forçado; Moçâmedes; resistências.

* Este artigo é resultado de pesquisa realizada durante estadia como investigadora visitante em Lisboa no ICS com o Grupo de Investigação Impérios, Colonialismo e Sociedades Pós-coloniais. Agradeço o debate, as sugestões e o incentivo dos colegas. Agradeço também as leituras críticas dos pareceristas da Revista Mundos do Trabalho.

** Doutora em História Social pela Universidade de São Paulo (USP). Docente da graduação e da pós-graduação em História da Universidade Federal de São Paulo (UNIFESP). Orcid: https://orcid.org/0000-0002-8830-1267. E-mail: mlfoliveira@unifesp.br. 
Abstract: This article maps connections between men, knowledge and business linking Portugal, Angola and Brazil in the years 1840 to 1860. I investigated the circulation of commodities production knowledge, in order to scrutinize the practices of colonial administration, especially on the forms of recruited labor (specialized and manual) at that time for cruisers and anti-trafficking treaties. I aim to highlight the tensions, clashes and persistent modes of resistance be it by refusal to work, via escapes, institutional struggle or even war. The article is divides in four parts. Firstly I examine the circulation of ideas about military colonization during this period; then, I tried to acknowledge connections between Moçâmedes and Brazil; in a third part, I deal with the fundamental presence of freed and slave workers. Finally, I focus on continuous wars fought in the region, especially in the last years of the 1850s. Throughout the article, there are some trajectories that reveal Atlantic routes in business and colonial administration: individuals trained in the political battles of the $1820 \mathrm{~s}-1830$ who took on new (old) roles in the new (old) times of colonization.

Keywords: Military colonization; forced labour; Moçâmedes; resistances.

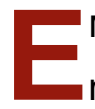

M PRINCíPIOS DE 1840, chegava em Lisboa o relatório da expedição do oficial da marinha Pedro Alexandrino da Cunha para o porto de Pinda e a baía de Moçâmedes, ao sul de Benguela. Pragmático, o capitão da curveta Isabel descreveu o melhor local para o atracadouro, identificou uma boa fonte para aguada, elogiou a salubridade do clima, a urzela "de superior qualidade", a grande disponibilidade de peixe. Com olhar treinado, disse que o gentio tinha "índole pacífica", eram "mui tratáveis", indicou as preferências dos tipos de miçangas e de tecidos de cada grupo que habitava o local, assim como relatou as brigas internas, instrumentalizando os poderes coloniais. Descreveu as plantações que faziam de milho, feijão, mandioca, abóboras, os "incalculáveis" rebanhos bovinos que possuíam, "capaz de suprir as exigências da mais vasta especulação comercial, a quererem aqueles povos vendê-lo, como é provável, mas não certo", pois os sobas tinham muito orgulho do rebanho, não gostavam de se desfazer dos animais. ${ }^{1}$

Passados menos de 20 anos, era outra a situação dos grupos conhecidos por Alexandrino da Cunha. As terras mais férteis tinham sido distribuídas aos colonos brancos, como esclarece o soba Quipolla, em petição enviada ao governador local em 1857:

Diz o soba Quipolla, que tendo sido distribuídas aos brancos todas as terras que ele e sua tribo ocupavam, não tem local onde possa estabelecer as suas libatas e currais para os gados; e como apenas restam para distribuir as várzeas dos Carpinteiros; e uma outra pequena já dentro da boca do rio Bero, as quais, apesar de estéreis, servem ao menos para nelas terem suas habitações e currais (...) porquanto não permitindo os brancos que ele estabeleça as suas libatas e currais em suas terras, ou o suplicante obtém

1 AHU, SEMU, ADGU, Angola, caixa 590, relatório de 20 jan. 1840. Doravante indicarei AHU e o número da caixa (sem referir SEMU, DGU, Angola, pois todas as caixas são desse fundo). 
local para tais fins ou não podendo sofrer os contínuos prejuízos (...) nem os maus-tratos dados aos seus pastores. ${ }^{2}$

O governador achou a petição "muito justa" e por isso concedeu o terreno e mandou dar posse registrada para a "tribo quipolla que em princípio ocupava as terras (...) e foi pouco a pouco retirando à medida que o governo as distribuía aos colonos que aqui chegavam". Ficaram, afinal, com aquelas terras estéreis, mas não por muito tempo. Em 1861, o secretário do governo de Moçâmedes apossou-se daquelas terras, "privando aquela pobre gente dos seus frutos, pois que corridos e espancados (...) abandonaram por uma vez as suas terras e plantações". Segundo o governador, a tribo, em vista dessa perseguição, internou-se para as terras de Campangombe, Hoke, onde "começaram a assassinar e roubar todos os europeus". 3

Nessa época, já havia Câmara Municipal funcionando em Moçâmedes, diversos engenhos, plantações de algodão, as importantes fazendas de salgas de peixe. Em 1857, foi aprovado pelas câmaras em Lisboa um decreto pela abertura do porto a todas as nações, pagando os mesmos direitos das alfândegas de Benguela e Luanda. ${ }^{4}$ Virou rota dos baleeiros americanos que paravam para se abastecer, movimentando a economia local. Entrou também na rota dos navios de comerciantes que traziam gêneros e levavam sobretudo urzela e algodão. Os engenhos produziam aguardente e açúcar para o mercado angolano. Para a segurança do "estabelecimento", a fortaleza de São Fernando, em 1858, tinha 500 homens, em geral ficavam cerca de 350 na vila, os outros destacados no sertão.

Em 1860, a vila sofreu um forte ataque de milhares de guerreiros nanos que desceram dos sertões e queimaram casas e fazendas, levaram animais, aterrorizando os brancos ali residentes. O engenho de açúcar de Bernardino Figueiredo, considerado fundador da colônia, foi completamente destruído. Para se recuperar, foi para Lisboa conseguir crédito. Um ano depois, estava de novo na sua fazenda, a Purificação da Luta, mas agora com um pequeno

2 Petição e auto de posse de 28 nov. 1857 encaminhadas em anexo ao ofício do governador Costa Leal de 11 out. 1865 a Lisboa. Ambos documentos estão transcritos na dissertação de: SOUSA, Rosa Margarida dos Santos Almeida. Moçâmedes, 1840-1907: contribuição para o estudo da história urbana de Angola. Universidade de Lisboa, Departamento de História, 2002, p. 386. A historiadora Mariana Candido também citou essa demanda de quipolla pela leitura do governador de Benguela, e entendeu que não obtiveram a posse da terra, apenas o uso para pastagens. Esse uso acabou sendo bloqueado pelos fazendeiros e, em 1865, migraram para o interior. CANDIDO, Mariana. Conquest, occupation, colonialism and exclusion: land disputes in Angola. In: SERRÃO, José V. et alli (orgs.). Property rights, Land and Territory in the European Overseas Empires. CEHC-ISCTE-IUL, 2014, p. 228-229. De qualquer maneira, a conclusão é a mesma: buscaram resistir usando as ferramentas institucionais, mas acabaram expropriados. Candido chama atenção para a mudança no valor da terra para a administração portuguesa nesse período após o final do tráfico negreiro. A apropriação dos territórios pelos governadores portugueses sinalizava para a passagem de um controle sobre o uso comunitário da terra pelas tribos avassaladas, para a proteção da conquista da terra e o incentivo à propriedade privada. Se antes os negociantes locais buscavam o comércio das gentes, passou a haver uma corrida para a garantia de concessões e títulos.

3 Em 1865, no ofício citado acima, denunciava o capitão Mendonça e o seu enteado capitão Miguel por apossarem-se das terras e plantações da tribo quipolla em 1861. A visão de Fernando Leal sobre manter uma posse para grupos locais apareceu em outro ofício de abril de 1857: "atualmente, junto a Moçâmedes, os terrenos susceptíveis de culturas estão distribuídos aos colonos e à tribo mundombes, sendo a parte que diz respeito a estes muito insignificante, mas que todavia não é prudente desapossá-los". Quipolla era um mundombe. AHU, caixa 623/1, 16 abr. 1857.

4 Correio Mercantil, 8 ago. 1857, em notícia dos decretos recentemente publicados pelo Diário do Governo de Portugal, acharam relevante tratar desse sobre Moçâmedes. 
forte e um destacamento de soldados. A construção de um forte especificamente para proteger o seu engenho, depois de dez anos de ocupação, mostra o imperativo da violência, a permanente tensão, assim como o interesse do ministério em Lisboa naquele porto ao sul de Benguela. Mesmo com as dificuldades e percalços, Portugal recrudescia sua presença na África, implementando "várias políticas para revitalizar os laços coloniais com Angola". ${ }^{5}$

Os sucessos em Moçâmedes ecoavam, de alguma maneira, as experiências já vividas no outro lado do Atlântico. No século XIX, a conquista do território e o domínio dos povos no Império do Brasil mantinham as práticas e dinâmicas dos tempos dos vínculos de subordinação política com Portugal. A consolidação do regime monárquico e a retomada do processo de "expansão para dentro"6 favoreceram novos projetos, particularmente a implantação de colônias militares. ${ }^{7}$ Em 1840, no Brasil, havia sido fundada a primeira colônia militar no Pará, com fins de potencializar a ocupação de regiões fronteiriças. Em 1850, o projeto ganharia forte impulso e em 1860 já eram 18 as colônias instaladas em diversas províncias. Entre as localidades, destaco as Matas do Jacuípe, na fronteira de Alagoas com Pernambuco. Em 1840, ali viviam grupos de indígenas, desertores, escravizados fugidos, em comunidades espalhadas pelas matas. O relato de um capitão do exército que se entranhou pelas matas em 1845 nas guerras contra Vicente de Paula deu notícia da vida rústica e autônoma desses grupos. Plantavam arroz nas várzeas dos rios, mandioca, criavam cabras e galinhas. ${ }^{8}$ Em

5 FERREIRA, Roquinaldo. Abolicionismo versus colonialismo: rupturas e continuidades em Angola (séc. XIX). In: GUEDES, Roberto (org.). África, brasileiros e portugueses, séculos XVI-XIX. Rio de Janeiro: Mauad $\mathrm{X}$, 2013. p. 137. Roquinaldo Ferreira ressalta as iniciativas para o estabelecimento de frentes agrícolas no período, mas observa que o comércio de exportação não cresceu tanto como o mercado interno. O debate na historiografia portuguesa sobre a viragem para a África no XIX, depois de perder o Brasil, é vasto. Valentim Alexandre defende a existência de um projeto colonial para a África no XIX português, já a partir da década de 1820, com avanços e recuos, mas desaguando em corrente majoritária a partir dos anos 1850, justamente com o final do tráfico de escravos para o Brasil. ALEXANDRE, V. Velho Brasil, novas Áfricas, Portugal e o Império (1808-1975). Porto: Afrontamento, 2000. p. 137.0 capítulo do livro O Império Africano, 1825-1890 (coordenado por Jill Dias e Valentin Alexandre, da série Nova História da Expansão Portuguesa. Lisboa: Editorial Estampa, 1988), relativo ao período, significativamente chama-se: Criando um novo Brasil, 18451870, e enfatiza o esforço colonizador de Portugal na articulação de redes de comércio e investimentos agrícolas, mas sempre disputando espaço com as redes de tráfico de escravos para Cuba, EUA e Antilhas francesas.

João P. Marques tem questionado a natureza desse projeto colonial, argumentando que eram iniciativas dispersas, com pouco efeito concreto, sobretudo porque não havia "em termos de interesse de classe, uma tendência colonialista no Portugal de então", não havia uma "burguesia profundamente interessada na África naquele período", quadro que mudaria no final do XIX. MARQUES, João P. Uma revisão crítica das teorias sobre abolição do tráfico de escravos português. Penélope, Revista de História e Ciências Sociais, Lisboa, n. 14, p. 95-118, 1994; e Avaliar as provas, resposta a Valentim Alexandre. Penélope, Lisboa, n. 15, p. 143-156, 1995. Gabriel Paquette reitera a importância dos debates sobre propostas coloniais para África de 1820 a 1850 , chamando atenção para o período conhecido como da Regeneração de 1850, quando o governo português reorganizou o aparato administrativo para os negócios coloniais, reinstituindo o Conselho Ultramarino em 1851. Afirma, ainda, que esse momento consolidava posições e posturas debatidas nas décadas anteriores. PAQUETTE, Gabriel, After Brazil: Portugueses debates on Empire, c.1820-1850. Journal of Colonialism and Colonial History, v. 11, n. 2, Fall 2010.

Talvez o estudo mais contundente na percepção das mudanças do período seja o de: DIAS, Jill. Mudanças nos padrões de poder no hinterland de Luanda, o impacto da colonização sobre os Mbundu (1845-1920). Penélope, Revista de História e Ciências Sociais, Lisboa, n. 14, p. 42-94, 1994.

6 MATTOS, Ilmar R. Construtores e herdeiros: a trama dos interesses da construção da unidade política. Revista Almanack Brasiliense, n. 1, maio 2005.

7 Sobre o tema, veja: OLIVEIRA, Maria Luiza Ferreira. O Exército e a 'difícil luta contra a independência dos homens do campo': embates na construção do Estado no Brasil, 1840-1870. In: BARRETO, Adriana et alli (orgs.). Pacificar o Brasil, das guerras justas às UPPs. São Paulo: Alameda, 2017. p. 124-153.

8 OLIVEIRA, Maria Luiza F. As guerras nas matas de Jacuípe. Revista CLIO, Dossiê Nação, cidadania, 
1860, a colônia militar Leopoldina tinha mais de dois mil habitantes, já havia engenhos na região, os aldeamentos indígenas tinham sido remanejados e/ou extintos.

Neste artigo, pretendo trabalhar o tema da colonização em meados do XIX, período nem sempre privilegiado pela historiografia, tanto portuguesa como brasileira. A análise será sobre o caso de Moçâmedes em suas conexões com o Brasil. Reflito sobre a circulação de saberes de produção de commodities, buscando esmiuçar práticas da administração colonial, especialmente sobre as formas de arregimentação do trabalho (especializado e braçal) nesse momento dos cruzadores e dos tratados antitráfico, ressaltando as tensões, os embates e uma persistente resistência operando de diversas formas, fosse na recusa ao trabalho, na fuga, na luta institucional ou na guerra.

\section{Entre o Brasil e a África}

PODE-SE COMPARAR OS ESFORÇOS colonizadores da década de 1850, de Portugal em Angola e do Brasil em seu território? Entre tantas diferenças, há a dimensão da consciência de um novo tempo, uma disputa ressignificada, com novos elementos em pauta no século XIX liberal, pós-revoluções e independências.

Muito expressivo da perspectiva da corrida colonial é o texto escrito em 1846 por Simão José da Luz Soriano, chefe da repartição de Angola no ministério:

Enquanto a França cuida em se assegurar pelas armas da sua conquista de Argel, sem se esquecer dos meios de colonizar esta sua nova província; enquanto a Inglaterra, para quem parece pouca toda a extensão do mundo (...). Será Portugal espectador tranquilo de toda essa agitação e movimento da Europa civilizada? (...) atenção para os ricos domínios do sul de Benguella, ou mais particularmente para os sertões, que avizinham com Moçâmedes, que thes podem servir ainda de um novo Brasil. ${ }^{9}$

Entre 1842 e 1851, período em que ocupou o cargo, os papéis vindos de Angola passavam pelas mãos de Luz Soriano. A disputa política não era pequena, mas Soriano e o ministério foram bem-sucedidos nas Cortes. ${ }^{10}$ Aparece a perspectiva de um novo Brasil, foi um tema recorrente na pena dos envolvidos na colonização da África na época, como a historiografia já frisou. ${ }^{11}$

insurgências e práticas políticas, 1817-1848, UFPE, 2015 - n. 1, v. 2.

9 LUZ SORIANO, Simão José da. Memória sobre os sertões e a costa ao sul de Benguella, na província de Angola, pelo chefe da repartição de Angola. Annaes Marítimos e Coloniaes (doravante AMC), $6^{\mathrm{a}}$ série, parte não oficial. Lisboa: Imprensa Nacional, 1846.

10 Nos debates da Câmara, por ocasião da aprovação da proposta de lei do governo que destinaria 18 contos para apoiar a colônia em Moçâmedes, vê-se que o governo obteve ampla vitória na votação: 48 votos a favor e 5 contra. A reconstituição dos debates está em: AZEVEDO, José Manuel de. A colonização do Sudoeste angolano, do deserto do Namibe ao planalto da Huíla, 1849-1900. Tese (Doutorado em História) - Universidade de Salamanca, 2014. p. 87-92. Para João P. Marques, a prioridade dos deputados naqueles anos não era o ultramar. MARQUES, João P. Os sons do silêncio, o Portugal de Oitocentos e a abolição do tráfico de escravos. Lisboa: Imprensa de Ciências Sociais, 1999, p. 361

11 ALEXANDRE, Valentim. Velho Brasil, novas Áfricas, Portugal e o Império (1808-1975). Porto: Afrontamento, 2000. 
Homens envolvidos na administração portuguesa, intelectuais, preocupavam-se em "investigar as causas da decadência" das "possessões ultramarinas"; espécie de mote de fundação da Associação Marítima e Colonial, surgida em 1839 com a chancela de um Decreto Real, com 77 sócios. ${ }^{12}$ Para a associação, era preciso investir nos estabelecimentos portugueses na África, abandonados enquanto privilegiara-se o Brasil. Na revista da associação pode-se acompanhar o debate sobre modelos de colonização. Discutiam os métodos franceses, ingleses e as companhias monopolizadoras de comércio; havia a perspectiva de que era preciso manter uma legislação protecionista. ${ }^{13}$

Para o autor de um artigo publicado n'O Correio Mercantil, um dos maiores jornais do Brasil, em 1859 esse cenário já tinha mudado, elogiava "a colonização rápida já começada em Moçâmedes e em vários pontos na África", o café ia dando "excelentes frutos", protegiam os investidores com subsídios, promoveram linhas de navegação a vapor e, o mais importante: "o colono, apenas chegado, pode logo empregar no seu serviço mais negros do que the poderia fornecer uma província inteira do Brasil". Era um escravista sem freios, para ele "não vinham mais negros para o Brasil pela hipocrisia sentimental da Europa, fazendo assim triunfar as nações que pretendem aniquilar este vasto império". Ecoava a propaganda portuguesa: "Portugal deve assustar-nos grandemente, porque vai ali inaugurar um segundo Brasil". Terminava exaltando a necessidade de investimento no Brasil, o caminho seria agora "o aumento da produção pela colonização". ${ }^{14}$

O movimento de interiorização do Estado no Brasil, expresso também na instalação de colônias militares nas matas, conectava-se aos debates sobre administração colonial na África, tanto na medida em que era pensado por homens com vivências e/ou experiências do império português, como porque a colonização comparada era um tema que circulava e pautava um esforço de colonizar "sendo moderno", ou seja, aumentando a produção para aproveitar a ampliação crescente das possibilidades de circulação das mercadorias no século XIX com a revolução tecnológica e dos meios de transportes, mas pisando em terreno movediço e em transformação quanto ao uso da mão de obra.

Tanto no Brasil como em Angola, o trabalho forçado dos africanos livres, dos indígenas e dos libertos foi essencial para alavancar esses novos 'estabelecimentos' colonizadores. Personagens importantes no processo são os militares inseridos na administração. Eram engenheiros, médicos, estrategistas. Além das armas, manejavam cada vez mais as técnicas tropicais de cultivo e recrutavam homens para as armas e para o trabalho.

12 AMC. v. 1. Lisboa: Imprensa Nacional, nov. 1840. Sobre a fundação da Associação e o apoio do governo à iniciativa, ver: PAQUETTE, After Brazil: Portugueses debates on Empire, c. 1820-1850. Journal of Colonialism and Colonial History, v.11, n. 2, p. 5, Fall 2010.

13 PAQUETTE, Gabriel. Imperial Portugal in the Age of Atlantic Revolutions, The luso-brasilian World, 1770-1850, New York: Cambridge University Press, 2013. p. 354-355.

14 Correio Mercantil. Rio de Janeiro, 23 dez. 1859, p. 2 (ed. 354). A matéria era intitulada "Colonização e navegação", não vinha assinada, foi incluída na seção Publicações a pedido. 
Um dos principais ideólogos da colonização militar no Brasil nessa época foi Francisco Soares d'Andrea, um militar português que veio para o Brasil acompanhando D. João VI como segundo-tenente da Armada Real, em 1808. Era engenheiro, tinha já concluído os estudos na Academia Real da Marinha. Teve carreira política de sucesso, foi presidente de várias províncias. Em 1849, foi consultado sobre o regulamento elaborado pelo Conselho de Estado do Império do Brasil para a colonização militar a ser empreendida nas matas entre Alagoas e Pernambuco. ${ }^{15}$ Naquela altura, já há 40 anos no Brasil, tinha intimidade com o território, discorria sobre diversos rios, relevo, áreas de fronteira, falava sobre estradas necessárias. Tinha, sobretudo, experiência com os vários "outros" habitantes do país, os diversos grupos indígenas rebeldes no Pará, os indígenas e africanos na Bahia, os botocudos em Minas Gerais. Defendeu as colônias "para forçar à civilização e à obediência essas hordas selvagens que ocupam vastas extensões de terrenos, ou para impor respeito aos povos turbulentos e dispersos", assim, "desenganando os índios da impossibilidade de existirem errantes". Depois de expor o seu projeto pessoal, amplo, da colonização militar para o Brasil (queria pelo menos 50 colônias), o experiente militar e político respondeu à pergunta que lhe tinha sido feita sobre a necessidade de uma ou duas colônias naquela fronteira específica: "uma de 200 praças julgo sobeja para toda a mata de Jacuípe, e bastará para isso mesmo uma colônia, porque se não trata de ir bater rebeldes, trata-se somente de Ihes não deixar levantar cabeça."16

Um dos militares do período que expressa a circulação no mundo atlântico, a imbricação entre a vida militar e a vida política, a participação no campo de batalha e no planejamento administrativo é o português Sá da Bandeira. Em 1828, Bernardo de Sá Nogueira de Figueiredo, o futuro marquês de Sá da Bandeira, esteve no Brasil, fugindo da guerra em Portugal e buscando articular a resistência a D. Miguel. Nessa viagem, tinha o olhar atento, tomava notas sobre os mais diversos temas, em papéis de diferentes tamanhos, de maneira errática: interessou-o as jangadas e os remeiros, a profusão de insetos e de répteis, o jardim botânico em Olinda, a fruta-pão (anos depois providenciou o envio de árvores de fruta-pão para Angola, além de outras plantas do jardim de Olinda). ${ }^{17}$ Travou relações com o cônsul de Portugal no Rio de Janeiro e promoveu, durante sua carreira em Portugal, a aproximação e a circulação de homens e saberes entre Portugal, o Brasil e a África.

Sá da Bandeira tinha planos, em 1838, de mandar reconhecer o rio Zaire - a ideia era ter subsídios para escolher o melhor ponto para estabelecer de um lado uma fortaleza militar e do outro uma colônia agrícola, pois assim haveria mútuo socorro "entre os estabelecimentos e seguraria muito melhor a nossa fronteira (...). Dever-se-á persuadir aos colonos a que plantem

15 OLIVEIRA, Maria L. F. No centro das matas: as colônias militares e os embates dos anos 1850. In: NEVES, Lucia Neves et alli (org). Elites, fronteiras e cultura no Império do Brasil. Rio de Janeiro: ContraCapa, 2013. p. $111-137$

16 IHGB, Coleção Marquês de Olinda, lata 206, doc. 6, Carta de Francisco J. S. Soares de Andrea ao V. de Olinda, s/d. Grifo meu.

17 Arquivo Histórico Militar (Lisboa), cód. 3/18/11/17/03 - Arquivo particular de Sá da Bandeira. Bernardo de Sá Nogueira. Estada no Brasil, escritos diversos feitos entre dezembro de 1828 e janeiro de 1829. 
cafezeiros ou algodoeiros". ${ }^{18} \mathrm{No}$ Brasil, iniciativas semelhantes ocorriam nesse mesmo período. Nos primeiros anos da década de 1840, foram organizadas expedições de reconhecimento e mapeamento do rio Tibagi e do rio Paraná; esse conhecimento instruiu o projeto de criação de uma colônia militar, juntamente com aldeamentos indígenas - de um lado do rio Tibagy foi construído o grande aldeamento São Pedro d'Alcântara, na outra margem foi instalada a colônia militar do Jatahy -, ajudando-se mutuamente. A colônia funcionava como porto para a navegação fluvial e buscava facilitar a ligação com o Mato Grosso - rota considerada estratégica, tanto para a garantia das fronteiras como para a expansão das áreas produtivas. ${ }^{19}$

Outro especialista defensor da colonização militar no Brasil era também um português naturalizado brasileiro que fez carreira no serviço público, Rufino Vasconcellos. Esteve no Maranhão em 1854 em uma expedição para investigar possibilidades de extração de minérios e conheceu a colônia militar do Gurupi, encravada no meio dos quilombos, em região rica. Para ele, era central para o sucesso da colonização militar brasileira o empenho do governo. ${ }^{20}$ Talvez por isso tenha gostado do livro sobre a Argélia, do abade Landmann, para quem "será necessário que nossos estabelecimentos na África sejam empreendimentos nacionais e não individuais, e sejam ao mesmo tempo agrícolas, religiosos e militares". ${ }^{21}$ Ele era da direção da Sociedade Auxiliadora da Indústria Nacional e empenhava-se na publicação do periódico editado pela associação que circulava pelo Brasil, distribuído para as capitais e para diversas câmaras municipais dos interiores. Não considerava que o Brasil tivesse soberania sobre seu território, o governo brasileiro precisaria empreender uma política colonizadora.

Em 1854, nesse periódico, foi publicado um amplo estudo sobre a "proteção eficaz que tem dado o governo francês à (...) Argélia, que pode concorrer com o trigo e a cevada para o abastecimento dos mercados da Europa" e "transforma-se-á no jardim da França durante o inverno, fornecendo-Ihes ervilhas, aspargos, goiabas, bananas". ${ }^{22}$ Era o tempo de celebrar a vitória da mercadoria, ocorrida - o periódico frisava - com o empenho do governo francês.

Sobre Angola, havia informes nos jornais brasileiros quase como se fosse outra província; publicavam-se os navios em trânsito para Luanda, Benguela e Moçâmedes, os leitores sabiam que o governador-geral mandara vir camelos de Tenerife, ou que uma nova estrada ia sendo feita. Acompanhavam, também, o andamento da colônia de Moçâmedes, a guerra em Ambriz, assim como os debates e tensões da vida política portuguesa. Eram mundos próximos. ${ }^{23}$

18 AHU, caixa 587, maço 9, relatório ao Sr. Visconde Sá da Bandeira, 6 ago. 1838. Antônio Manuel de Noronha citou no relatório as propostas de Sá da Bandeira.

19 Ver: Jéssika de Aquino Bezerra. Civilizar os sertões, consolidar o Estado. A colônia militar do Jataí e os aldeamentos indígenas no Tibagi (1845-1897). (Dissertação (Mestrado em História) - UNIFESP, 2015; AMOROSO, Marta. Terra de índio, imagens em aldeamentos do Império. São Paulo: Terceiro Nome, 2014.

20 Colônias Militares. Memória por José R. R. Vasconcellos, chefe de seção da 4ª. Div. Geral da Secretaria de Estado dos Negócios da Guerra, 1865. Biblioteca Nacional do Rio de Janeiro. Manuscrito.

21 LANDMANN, L’Abbé. Les Fermes du Petit Atlas, ou Colonisation agricole, religieuse et militaire du nord de l'Afrique. Paris: Chez Perisse Frères, Libraires, 1841.

22 Desenvolvimento agrícola e industrial da Argélia. O Auxiliador da Indústria Nacional, periódico da Sociedade Auxiliadora da Indústria Nacional, n. 1, p. 419-423, Rio de Janeiro, Typ. da Viúva Vianna Júnior, jul. 1854.

23 Exemplo de um jornal noticiando acontecimentos em Angola: Jornal do Commercio, Rio de Janeiro, 10 maio 1855; na primeira página, sobre Moçâmedes ter passado à categoria de vila. 
Experiências francesas na Argélia forneceram os modelos mais valorizados, tanto para os militares luso-brasileiros em atuação no Brasil quanto para os portugueses. Para o governador de Moçâmedes, o capitão Fernando da Costa Leal, as memórias do marechal Bugeaud, ex-governador da Argélia, deveriam ser estudadas, "atentos os brilhantes resultados que têm tido os ensaios propostos por este homem eminente (...) o da colonização militar que com mais ou menos modificações se poderia adotar no nosso continente de África". ${ }^{24}$

Na prática, o incentivo do governo português para produzir "em grande escala os gêneros chamados coloniais", o plantio da cana-de-açúcar, algodão, café, passava por tentar aproveitar a experiência brasileira. ${ }^{25}$ Ao aceitar o cargo de governador-geral de Angola, o vice-almirante Antônio Manoel de Noronha elaborou um detalhado programa de governo e encaminhou para o ministro Sá da Bandeira em agosto de 1838. Sugeria que o governo instalasse um Engenho Nacional, "mandando ao mesmo tempo ir de Pernambuco dois mestres de fazer açúcar e dois aguardenteiros para dirigirem os respectivos trabalhos"; além disso, o governo deveria dar para os lavradores "todo o feijão, milho e abóboras para poderem plantar entre a cana, conforme o uso das roças do Brasil". O excedente poderia ser empregado na criação de porcos, seguindo o exemplo do que "sucede nas províncias de Minas Gerais e São Paulo que exportam todos os anos mais de 50 mil arrobas de carne salgada ou ensacada daqueles animais". ${ }^{26}$ Sá da Bandeira estudou o relatório, aprovando com entusiasmo grande parte das propostas, como se vê nas anotações que deixou nas margens do documento.

Nesse processo, houve circulação no Atlântico por brasileiros ou por moradores no Brasil que foram para Angola, seja levando conhecimentos técnicos, práticas agrícolas ou como mão de obra. Para o estabelecimento de um engenho de fabricar açúcar e aguardente em Luanda, mandaram buscar um "mestre de fazer açúcar, de 18 anos de prática em Pernambuco". ${ }^{27}$ Assumiam também o papel de povoadores, vindos da ex-colônia, para outra vez serem colonos (refundando relação há pouco rompida). Já nos anos 1850, Cândido Augusto Fortunato da Costa, um dos maiores produtores de café de Angola, publicou um

24 Costa Leal afirmou isso em relatório para o ministro da Marinha e Ultramar em 31 dez. 1855. Annaes do Conselho Ultramarino, parte oficial, série I, fev. 1854 a dez. 1858. Lisboa: Imprensa Nacional, 1867. p. 294. Alfredo de A. Felner atribui à leitura da obra de Bugeaud a decisão de Sá da Bandeira pela criação da Colônia Militar da Huila, em 1857; FELNER, Alfredo de A. Angola, apontamentos sobre a colonização dos planaltos e litoral sul de Angola. Lisboa: Agência Geral das Colônias, 1940, 3 vols. p. 40, v. 1.

Como salienta Cristina Nogueira, "não existiram modelos de colonização aplicados de forma sistemática no tempo e no espaço", mas pode-se observar que "ao final do século XIX, Portugal foi invariavelmente colocado ao lado da França quanto aos modelos de colonização escolhidos"; SILVA, Cristina N. da. Modelos coloniais no século XIX (França, Espanha, Portugal). In: E-legal History Review, n. 7, 2009.

25 Aida Freudenthal chamou a atenção para a importância dessa conexão: "a experiência brasileira no domínio agrário foi sem dúvida a mais decisiva na expansão de um setor privado em solo angolano". A autora valorizou menos a dimensão pública, as ações do governo. Cf. FREUNDENTHAL A. Arimos e Fazendas, a transição agrária em Angola, 1850-1880. Luanda: Edições Chá de Caxinde, 2005, p. 126.

$26 \mathrm{AHU}$, caixa 588. Relatório oferecido ao $\mathrm{Im} .^{\circ}{ }^{\mathrm{Exm}} .^{\circ} \mathrm{Snr}$. Visconde de Sá da Bandeira, por Antônio Manoel de Noronha, 6 ago. 1838.

27 AMC, n. 4. Lisboa: Imprensa Nacional, fev. 1841. p. 157. Nesse processo, os cônsules eram agenciadores de mão de obra tanto braçal quanto especializada; o de Pernambuco arrumou também dois "súditos franceses moradores em Pernambuco há 16 anos, sendo um mestre, pessoa hábil e capaz de dirigir qualquer estabelecimento d'aguardente, ele pode dirigir o assentamento de quaisquer caldeiras e montar as máquinas de destilação". Sá da Bandeira anotou ao lado: "muito bom!". E ainda, "Antonio Monte Ferraz, súdito brasileiro, mestre de açúcar, embarcado em 31 de março de 1839”. ANTT, MNE, caixa 309, mf3509, ofício 27 abr. 1839. 
texto compartilhando sua experiência: "quando me estabeleci neste distrito de Cazengo, para me dedicar à cultura de café, desejei assemelhar-me o mais possível em meus trabalhos aos que se fazem no Brasil...". ${ }^{28} \mathrm{O}$ Brasil era, na prática, a principal referência. ${ }^{29}$

Os papéis se invertiam - a ex-metrópole buscava métodos de exploração colonial com a antiga colônia. Em 1848, instruções elaboradas para o governador recomendavam:

Com V. Ex. ${ }^{a}$ irá provavelmente uma máquina do último aperfeiçoamento para descaroçar e limpar o algodão, mas esta máquina, talvez que por muito complicada para as mãos de preto, deva ser substituída com vantagem pelas de muito mais simples manejo, e que no Pará e Pernambuco se denominam engenhocas. ${ }^{30}$

A experiência em Pernambuco, terra do açúcar e do algodão, por parte dos portugueses que iriam para Moçâmedes, dava um peso e um valor para o grupo que certamente contaram muito no interesse despertado em Lisboa.

\section{De Pernambuco para a Sintra da África, Moçâmedes}

DUAS IMPORTANTES BASES de exploração foram fundadas em Angola entre 1838 e 1840: o presídio Duque de Bragança e Moçâmedes. Eram duas novas frentes de ocupação, uma no sul, abaixo de Benguela, fronteira que ia sendo disputada - ter um porto no litoral sul era estratégico, ainda mais na foz de importante rio para interiorizar a colonização; a outra, no distrito de Luanda, no interior, na direção de Cassanje, encravada entre o território Mbondo e Jinga, naquele momento o mais avançado posto militar português. O presídio Duque de Bragança foi mandado instalar pelo governador Bernardo Vidal, após duras batalhas. A fundação vinha carregada de expectativas. ${ }^{31}$

Em abril de 1839, Noronha traçou ambiciosos planos para o Duque de Bragança e querendo construir os "fundamentos desse vasto edifício"32 enviou "os pretos tomados pelo brigue Audaz em Benguela para o comandante do forte os aplicar sob sua direção a lavrarem as terras" e mais "160 vadios que o cônsul do Rio de Janeiro remete para aqui com o título de colonos", ${ }^{33}$ eles seriam organizados em corpos, disciplinados, dirigidos por militares para

28 Ao longo do texto, no entanto, mostra como seguir o método do Brasil não foi bom, precisou observar "como os pretos faziam, o regime de sol e das chuvas era muito diferente", era necessário mais sombra e de árvores específicas - foi acertando, agora tinha 8.760 pés, perdera mais de 15.000 por usar método brasileiro. Apontamentos de um agricultor em benefício dos amantes da cultura do café. Fazenda d'Agoas Doces, 16 nov. 1854. Boletim do Governo Geral da Província d'Angola (doravante BOGGPA), n. 485, 13 jan.1855, p. 6.

29 Não era, por certo, o único modelo. Os anais do Conselho publicavam inúmeras matérias sobre avanços agrícolas, novos maquinismos, muitos versando sobre o Brasil, mas também sobre outros locais. Já na pena dos administradores, na correspondência oficial, as referências mais frequentes são à expertise brasileira.

30 AHU, caixa 612. Instruções ao Governador-Geral de Angola Adrião Accacio, 27 mar. 1848.

31 O governador B. Vidal afirmava com olhar prático, explicitando a dimensão comercial da ocupação em presídios: "mais saudável e mais fértil que nenhum dos outros que há na África Oriental e que passado um ou dois anos poderá render 6:000\$000 anuais". AHU, caixa 587, ofício de 8 nov. 1838.

32 AHU, caixa 588. Relatório de Noronha para Sá da Bandeira, 20 abr. 1839. "O distrito Duque de Bragança é o lugar mais sadio de todos os pontos do interior d'África (...) a todas estas vantagens acresce a da sua posição geográfica (...) fazer de Luanda um dos pontos mais comerciais do globo."

33 AHU, caixa 588. Ofício de Noronha, 20 abr. 1839. João Baptista Moreira promoveu o embarque de 165 


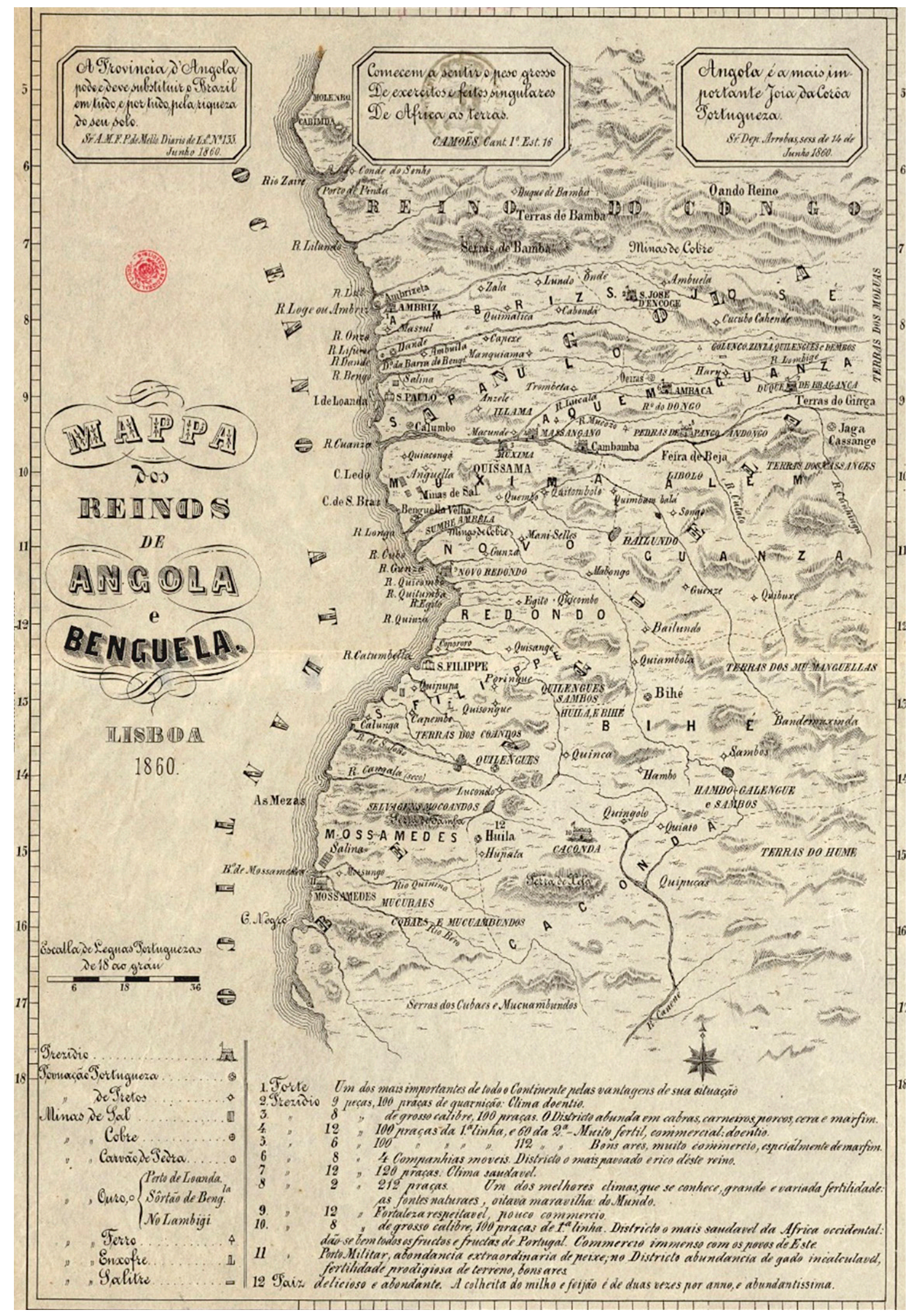

Mapa dos reinos de Angola e Benguela.

Lisboa: Lith. de Castro, 1860. Acervo da Biblioteca Nacional de Portugal.

Vê-se que foi um mapa desenhado para propaganda desse Novo Brasil, como vai no cabeçalho; atente-se para as legendas ressaltando as qualidades, expressas nas forças militares, no clima e na fertilidade. Também indicava os minérios disponíveis e a localização das minas. 
se "aplicarem ao trabalho da cultura nas terras." ${ }^{34}$ Noronha acreditava que teria problemas com os homens vindos do Rio de Janeiro e pedia alguns "casais de verdadeiros lavradores" dos Açores e também mulheres brancas "para casarem com os tais vadios do Rio". ${ }^{35}$ Eles plantariam algodão e café.

Eram várias as frentes acionadas para mobilizar mão de obra no esforço da colonização: africanos que seriam vendidos como escravos tornavam-se libertos obrigados ao trabalho, portugueses pobres que "inchavam" a cidade do Rio de Janeiro e cruzariam de novo o Atlântico para novas paragens, mulheres pobres vistas como reprodutoras, lavradores buscando escapar da miséria, muitas vezes enganados, vinham das ilhas dos Açores ou da Madeira.

Pode-se documentar o envolvimento do Ministério dos Negócios do Ultramar com Moçâmedes a partir de 1840, após a expedição citada no começo do texto, e da decisão de mandar instalar ali uma fortaleza. Mas, com a queda de Noronha do governo-geral de Angola, foi dominante a ocupação pelas feitorias e pelos traficantes. O envolvimento do ministério com o tema, nesses anos, era irregular: ofícios esporádicos remetiam ao assunto; foi concluída apenas uma parte da fortaleza que funcionou como ponto de apoio das feitorias e como um marco de posse. Em 1845, Alexandrino da Cunha (o comandante da expedição exploratória) assumiu o governo- geral de Angola e buscou refrear essa dinâmica, atacando os traficantes, incentivando a coleta da urzela, as salgas de peixe e a agricultura.

Simão José da Luz Soriano era secretário do ministério nessa época. Foi em 1846 que publicou nos Anais Marítimos e Coloniais a memória sobre Moçâmedes e os sertões, inspirado nos relatos da expedição de Alexandrino e nos papéis do ministério. Apelidou a região de Novo Brasil.

Foi também Alexandrino da Cunha que nomeou, em 1846, Álvaro d'Andrea, um jovem oficial da marinha, quadro técnico, para comandar o local, nesse espírito de incentivar novas formas de colonização. Em 1848, o ministério pediu para Álvaro d'Andrea opinar sobre as instruções que o governo preparara para o próximo governador, versando sobre maneiras de ocupar uma região de fronteira, matas e sertões, ponderando sobre a questão das populações locais, as possibilidades de investimento e de renda. Era chamado a opinar sobre formas de colonização, assim como seu tio, Francisco José de Souza Soares d'Andrea, no outro lado do Atlântico.

homens no Rio de Janeiro. O cônsul em Pernambuco enviou colonos ao abrigo do decreto, mas em remessas menores. ANTT, MNE, caixa 309, mf3509.

34 Os libertos trabalhariam "até que estejam em condições de viver por si". Ou seja, entendia que aqueles homens resgatados não tinham autonomia, eram como crianças. Para os "vadios" do Rio de Janeiro, o Conselho de Governo de Angola arbitrou em 100 réis diários e uma porção de farinha para cada um. AHU, caixa 588, ofício de 20 abr. 1839.

35 "A colonização dos brancos, que em grande numero e por grande preço foram transportados do Brasil, para onde a maioria fora iludida. O maior número foi destinado para o presídio do Duque de Bragança, recentemente conquistado (...) distribuíram-se-lhe terras, alguns instrumentos e meios. O presídio do Duque de Bragança é já pela sua população e situação um dos mais importantes." Relatório do Ministério do Ultramar, apresentado às câmaras na sessão extraordinária de 1840. In: AMC, n. 4. Lisboa: Imprensa Nacional, fev. 1841. p. 159. 
Conhecia com intimidade a baía de Moçâmedes e os seus sertões. Não dominava a escrita como o tio e tinha menos projetos na cabeça - era ainda jovem e sua vocação não parecia ser a de estadista. Era também mais cético. Para ele, havia muitas inexatidões nas "informações dadas pelos diversos exploradores que têm andado nestes sertões"; corrigiu o nome e o curso de rios assim como a descrição das montanhas. Mas asseverou que a ideia que o governo fazia da região "era muito mais vantajosa do que se deve", a Huila "não possui, certamente, um terço da fertilidade que se the atribui". Sobretudo o governo se achava muito enganado sobre o caráter que "atribuem aos habitantes destas terras: em vez de dócil e pacífico, mais se deveria dizer caráter traiçoeiro e covarde (...) o seu fim é que, estabelecendo-se os portugueses entre eles, construindo fortes, os venha a proteger contra as excursões e ataques de seus vizinhos para assim poderem roubar sem serem roubados". Opinou pelo emprego de "bougues para obstar a transbordação do rio"36 e contou das plantações de milho, hortaliças e da experiência bem-sucedida na produção de farinha de mandioca que ele mandara fazer. Enquanto o tio pretendia usar a ação militar para a vigilância e a submissão dos povos locais, o sobrinho observava como as populações locais usavam da força portuguesa em interesse próprio, não seguiam exatamente os desígnios imaginados pelo colonizador.

Em julho de 1848, o ministério recebeu a demanda para a instalação de uma colônia agrícola de luso-brasileiros de Pernambuco em "algum ponto do império português". A partir da escolha de Moçâmedes para receber o empreendimento, passou a haver agilidade nos despachos do ministério em Lisboa com relação ao tema, assim como continuidade nas ações. Em outubro, já era publicada em Lisboa uma detalhada portaria ordenando o processo para a criação da colônia. Foi tudo muito rápido.

Em agosto de 1849, chegaria em Moçâmedes Bernardino Freire de Figueiredo Abreu e Castro com 174 portugueses de Pernambuco para implementar uma colônia agrícola junto a um destacamento militar composto por 100 homens vindos de Lisboa. Em 1850 e 1851, outras levas de colonos portugueses do Brasil viriam do Rio de Janeiro, Bahia e do Recife, fazendo com que "em menos de dois anos chegassem cerca de 430 luso-brasileiros a Angola - isto é, quase um quarto de toda a população branca ali residente". ${ }^{37}$ Viriam também mulheres brasileiras.

Ao abandonar o Recife e ir para a África, Bernardino Figueiredo de Abreu expressava e realizava o movimento do desejo de Luz Soriano, fazendo o Brasil ser passado e investindo nessa África do futuro: uma nova Angola. Moçâmedes, um novo espaço de construção de

36 AHU, caixa 612. Álvaro J. de Souza S. Andrea, relatório, Quartel do Commando de Mossamedes, 20 nov. 1848.

37 PELISSIER, Rene. História das campanhas de Angola, resistência e revoltas (1845-1941). v. 1. Lisboa: Editorial Estampa, 1986. p. 179.

O segundo embarque de colonos para Moçâmedes foi no dia 13 de outubro de 1850. Em 1851, viriam da Bahia, na barca nacional Flor da Amizade, mais 79 colonos. SILVA, Raul José Candeias da. Subsídios para a história da colonização do distrito de Moçâmedes durante o século XIX. Lisboa: Centro de Estudos Históricos Ultramarinos, 1973, p. 26-27. AHU, livro 4, 1848-1850, p. 262; caixa 614, 1850; e caixa 615/A, 1851. 
riqueza que poderia e deveria superar o trópico ocidental. Não por outro motivo, Luz Soriano deu todo o apoio que Bernardino pediu.

Angustiado e oprimido pelo antilusitanismo e pelas violentas disputas políticas na Recife dos anos 1840, especialmente os mata-marinheiros (motins populares da época da Praieira), Bernardino enviou um pedido para o governo português para ser encaminhado, junto com outros insatisfeitos, para algum ponto do império português. Escreveu ao Ministério do Ultramar no dia 13 de julho de 1848, pouco depois "dos horrorosos acontecimentos dos dias 26 e 27 de junho, quando cadáveres ensanguentados de portugueses foram arrastados pelas ruas, roubando-se-lhes seus haveres"; eram "cenas imorais e aviltantes dos filhos baterem e assassinarem os seus pais". Seu pedido era também uma proposta. Já tomara diversas providências, conversara com o cônsul Joaquim Batista Moreira pedindo apoio, assim como já convocara pelo jornal adesões ao seu projeto. Ele enviava para Lisboa uma primeira lista de nomes de engajados e esclarecia que levaria

...dos mais úteis, que são os que entendem do fabrico dos açúcares e plantações de canas, e mesmo do tabaco e café, pois que vivo em relação com muitos engenhos, tenho neles arranjado vários, e ter-me-ei dedicado a conhecer com fundamento o modo mais profícuo de fazer o açúcar. ${ }^{38}$

Bernardino Freire morava há dez anos no Recife, onde envolveu-se com a vida cultural e política. Ao chegar, em 1839, foi dar aulas no Colégio Pernambucano, de um conterrâneo (José Soares de Azevedo, fundador do Instituto Arqueológico Histórico e Geográfico Pernambucano, em 1862). Era miguelista, lutou nas fileiras pelo absolutismo, foi jornalista em Lisboa trabalhando no Alcance e depois na redação do jornal Portugal Velho, jornais do partido absolutista que "acabaram depois de ter sido promulgada a Constituição Setembrista de 1838". ${ }^{39}$ No ano seguinte, decidiu abandonar Portugal. Ensinava latim, geografia e história - matéria pela qual tinha predileção. Em 1847, publicou um romance, Nossa Senhora dos Guararapes, considerado o primeiro "romance pernambucano" pelo historiador J. A. Gonçalves de Melo. Ansiava pelos tempos em que portugueses e brasileiros andassem juntos, sem "alucinações políticas". Pernambuco daquele tempo vivia em "mares turbulentos", precisando cultivar "valores morais... a dissolução moral traz a dissolução política". ${ }^{40}$ Significativamente, o engenho que Bernardino construiu em Moçâmedes chamava-se Purificação da Luta.

Bernardino era um ex-combatente, participara ativamente da revolta da Serra da Estrela em 1836, um professor e escritor que logo mudaria totalmente de ramo, tornando-se um

38 Bernardino Freire de F. Abreu e Castro. Petição dos portugueses de Pernambuco para serem conduzidos a um porto das nossas possessões da África ou da Ásia, 3 jul. 1848. Revista Arquivos de Angola, $2^{a}$ série, v. VI, Museu de Angola. Luanda: Oficina da Imprensa Nacional, 1949.

39 ALVES, Carlos Martins de Castro. Bernardino Freire de Figueiredo Abreu e Castro, bosquejo biográfico do colonizador de Moçâmedes, separata de Garcia de Orta. Revista da Junta de Investigaciones de Ultramar, Lisboa, v. 18, n. 1-4, 1970.

40 Bernardino Freire de Figueiredo Abreu e Castro. Nossa Senhora dos Guararapes: romance histórico, descritivo, moral e critico. 1847, edição fac-similar. Recife: Fundação de Cultura do Recife, 1980, 2 v. Com apresentação de José Antonio Gonçalves de Mello. p. 5. 
agricultor e senhor de engenho com dezenas de escravos na África. Na proposta que escreveu para o ministério, havia trechos que iam de encontro com as preocupações do momento: "temos na Ásia e na África uma superfície (...) d'onde podíamos tirar inúmeras vantagens e que só nos acarretam despesas."

Mostrava olhar bastante prático sobre a ocasião oportuna: "eu não acho para daqui arrastar muita gente para as nossas possessões, outra mais própria do que a atual enquanto está recente a lembrança dos horrores sucedidos". ${ }^{41} \mathrm{O}$ antilusitanismo e os atentados, eram, no fundo, um pretexto. Ele pedia um navio para transportá-los e um bom navio de guerra, armas, munições, ferramentas, provisões para os primeiros seis meses, lei isentando de direitos nas alfândegas de Portugal os produtos agrícolas da colônia por dez anos. Afirmava que seria bom já levarem "os arranjos para o estabelecimento de três engenhos "um cuja máquina de moer a cana tivesse por motor a água, outro animais, outro vapor: e se montassem por ora os laboratórios, vulgo assentamentos da forma comum". Ao lado desse trecho, está anotado: "o governo autoriza o proponente de acordo com o cônsul a comprar os três engenhos". Praticamente tudo o que ele pediu e propôs foi aceito.

Em março de 1849, o consulado português no Recife avisou que tinha entregado quatro letras de dois contos cada a Ângelo Francisco Carneiro "pela importância do custo de três engenhos e outros objetos destinados ao fabrico de açúcar", ${ }^{42}$ totalizando oito contos em moeda do reino. Ângelo Carneiro era "o mais bem-sucedido e notório negociante de escravos do norte do Brasil", como definiu o cônsul inglês Henry Cowper em $1842 .{ }^{43}$ Articulando os portos por vias oficias e pelos negócios, estavam os Moreira - representantes consulares de Portugal no Brasil. Joaquim Baptista Moreira, cônsul português em Pernambuco, foi da comissão promotora do primeiro embarque de colonos em 1849 e representava um dos importantes elos da corrente de negócios entre Pernambuco, Angola e Portugal em meados do XIX.44 As redes do tráfico atlântico seguiam ativas na colonização 'moderna'.

O desejo de interiorização da empresa colonial existia desde os planos de ocupação da baía de Moçâmedes em 1840. Bernardino Figueiredo, nomeado diretor da colônia, organizou em outubro de 1850 uma expedição para a região do Bumbo, composta pelo governador Antonio Sérgio, o almoxarife de Moçâmedes, dois colonos, três soldados e "uns 60 pretos, parte da Huila e parte da tribo quipolla". No Bumbo, anotou que "havia o perene rio, de que o gentio se serve para as suas plantações por um bem adiantado sistema de irrigação". A expedição seguiu passando pela Huila, Jau e Gambos. No território dos Gambos, havia

41 Bernardino Freire de Figueiredo Abreu e Castro, considerações e alvitres sobre a colônia fundar, Recife, 12 jul. 1848. In: Revista Arquivos de Angola, 1949.

42 Ofício do chanceler Miguel Joze Alves, encarregado do consulado de Portugal em Pernambuco para o ministro da Marinha e Ultramar, 3 mar. 1849. In: Revista Arquivos de Angola, v. VI, 1949. p. 102.

43 CALDEIRA, Arlindo Manuel. Escravos e traficantes no império português. Lisboa: A Esfera dos Livros, 2013. p. 289-291. De volta a Lisboa, em 1850, Ângelo Carneiro receberia o título de visconde de Loures em 1851.

44 Marcus Carvalho relata o vínculo dos irmãos Moreira com o tráfico, como Joaquim Moreira liberava embarcações de notórios traficantes em Recife. O patacho Providência, um navio negreiro, política, justiça e redes depois da lei antitráfico de 1831. Varia História, Belo Horizonte, v. 30, n. 54, p. 801, set.-dez. 2014. 
diversas plantações: milho, feijão, batatas, massango, massambala. Criavam gado, carneiros, galinhas e porcos. Bernardino dedicou várias páginas na descrição do encontro com o soba dos Gambos. Encantado por presenciar aquele momento, escreveu: "não vale tanto passar uma noite no Theatro de S. Carlos, ouvindo bem assinados e harmoniosos sons de música vocal e instrumental e vendo uma boa dança, como presenciar o recebimento que nos fez o soba dos Gambos". ${ }^{45}$ Depois do tratado assinado, ${ }^{46}$ o governador deu os seus uniformes para o soba, declarando que pediria ao governo a patente de coronel para ele. Deu também a espada, agradecendo em nome da rainha o "agasalho" que ele vinha dando aos portugueses em suas terras. ${ }^{47}$ No caminho de volta, pararam na casa do feirante Bernardino Brochado, ${ }^{48}$ que foi então nomeado regente interino dos Gambos.

Repetia-se estratégia secularmente utilizada: a troca de presentes, a assinatura de tratados, a promessa de um título português ao líder local, assim como a absorção nos quadros da administração colonial do negociante branco português que se aventurara e investira recursos próprios na fronteira do império. Menos de um mês depois do regresso da expedição, José Leite de Albuquerque, luso-brasileiro que em Pernambuco era feitor de um engenho e recrutado por Bernardino, decidiu explorar a África; foi com sua mulher e 14 pretos "já práticos trabalhadores de campo com uns 40 carregadores" para o Bumbo para montar e gerir um engenho. José Leite de Albuquerque seria senhor de engenho, hastearia uma bandeira portuguesa no forte que construiu com os próprios recursos e seria nomeado governador do Forte de São Sérgio, ${ }^{49}$ com o posto de capitão. O engenho, denominado Triumpho, foi bem-sucedido e cresceu; em 1864, era responsável por abastecer de aguardente e açúcar todo o interior do distrito. ${ }^{50}$

Foi rápida a instalação de uma dinâmica institucional em Moçâmedes, a criação do Conselho de Governo foi aprovada pela rainha em junho de $1850,{ }^{51}$ assim como foi nomeado um juiz ordinário. Em 1852, Moçâmedes participou das eleições para as Cortes e Bernardino Figueiredo foi para Luanda votar, pois foi o eleitor do distrito. De lá, mandou uma carta diretamente ao ministro. Começava, para enfatizar seu comprometimento, lamentando ter sido "obrigado a sair de Moçâmedes, pois desejava ver e observar a inundação do rio Bero". O envio da carta comprova o papel que conseguira adquirir, até poucos anos antes morava no Recife e sentia-se em grande medida um desterrado, agora era lido com atenção pelo

45 AHU, caixa 615/2. Memória da expedição aos Gambos, 30 dez. 1850.

46 Foi um caso de vassalagem voluntária, e vários termos do acordo foram ditados pelo soba. Sobre os tratados e a relação recíproca e, ao mesmo tempo, assimétrica, ver: CRUZ, Ariane Carvalho. Sempre vassalo fiel de Sua Majestade Fidelíssima: os autos de vassalagem e as cartas patentes para autoridades locais africanas (Angola, segunda metade do século XVIII). Caderno de Estudos Africanos, 30, p. 61-80, jul.-dez. 2015.

47 AHU, caixa 615/2. Memória da expedição aos Gambos, 30 dez. 1850.

48 Era também explorador, sertanista. Para Pinheiro Chagas, "um dos exploradores que mais se empenharam em percorrer e em descrever os territórios ao sul da província foi Bernardino José Brochado, que desde 1847 andava visitando os povos do Humbe, Camba, Mulondo, Quanhama". CHAGAS, Pinheiro. As colônias portuguesas no século XIX, 1811 a 1890. Lisboa: Livraria de A. M. Pereira Editor, 1890. p. 53.

49 AHU, caixa 617/1, ofício de 15 nov. 1851.

50 Relatório do governador do distrito de Moçâmedes, Fernando da Costa Leal, 30 set. 1864 apud SOUSA, Rosa, op. cit, p. 387.

51 AHU, livro 676, 1848-1850, p. 262, ofício de 14 jun. 1850. 
ministro; sequer encaminhava a carta pelo governador de Angola. E pedia, sem rodeios, pela mudança urgente do governador de Moçâmedes, o tenente-coronel José Herculano Ferreira Horta, que ficara pouco mais de um ano no cargo "cuidando de seus interesses", "de enriquecer rapidamente" com o tráfico que voltara em pontos de embarque entre Benguela e Moçâmedes. Arrematou a carta: "conhece-se a necessidade que temos de colônias, é preciso torná-las úteis e rendosas. É este o meu programa". ${ }^{52}$

\section{Trabalhadores da "civilização"}

EM MoçÂMEDES, a mão de obra dos libertos foi importante desde o início. Em fevereiro de 1840, já foram enviados de Luanda "quinze casais de libertos" para "o novo estabelecimento", trabalhariam na edificação das benfeitorias, nas plantações e nas salgas de carnes e peixes. ${ }^{53}$

No Brasil, africanos livres foram cedidos pelo governo para a abertura de estradas e para as colônias militares. Itapura em São Paulo e Jatahy no Paraná, por exemplo, contaram com a mão de obra de africanos livres. Em 1851, o ministério cedeu 100 africanos livres para a Sociedade Mineradora do Mato Grosso, companhia privada de grandes fazendeiros de café que obteve concessão do governo para buscar ouro em ampla região ao longo do rio Paraguai, oferecendo como contrapartida a construção de uma estrada e o empenho na 'pacificação' dos indígenas hostis. ${ }^{54}$ Os africanos livres estiveram nas obras públicas de Salvador, no Rio de Janeiro, na Fábrica de Ferro Ipanema, no Arsenal da Guerra e no da Marinha. Tanto os libertos em Angola como os africanos livres no Brasil eram produto das leis que proibiram o tráfico: tinham experimentado a viagem, tinham sido capturados e vendidos como escravos, mas foram "libertados" ou durante a viagem, ou no desembarque. No caso do Brasil, eram os que entraram no país depois de 1831 e quando pegos pelas autoridades no desembarque passavam a ser "africanos livres".

52 AHU, caixa 617, carta escrita em Luanda no dia 20 fev. 1852.

$53 \mathrm{Na}$ região havia abundante sal, o que facilitaria o processo, a produção de peixe seco seria das principais em Moçâmedes. Nessa primeira remessa do governador geral de Angola, além dos casais iriam mais "um adido e um moleque, todos da classe de libertos, apreendidos por contrabando de escravos nessa cidade", além de "um marinheiro e bem assim alguns cabindas ou marinheiros". AHU, caixa 590, ofício de 3 fev. 1840 e ofício de 16 fev. 1840. Havia sutis diferenças na situação dos libertos na África portuguesa no período. Os africanos libertos pela Comissão Mista Anglo-Portuguesa dispunham de uma custódia binacional e tinham o destino mais controlado, mas eram minoria; para Luanda, foram apenas 137 entre 1844 e 1870, sendo que até 1854 calcula-se em cerca de 3.000 os africanos libertos em Angola e, depois de 1854, as estimativas falam em 30.000. Esses números estão no estudo de COGHE, Samuël, The problem of freedom in a MInd Nineteenth - Century Atlantic Slave Society: The liberated africans of the Anglo-Portuguese Mixed Comission in Luanda (1844-1870). Slavery \& Abolition, 33:3, p. 479-500, 2012. Cristina Nogueira da Silva estudou os debates parlamentares sobre a condição dos libertos na África, assim como a jurisprudência sobre o tema. SILVA, Cristina Nogueira da. Constitucionalismo e Império, a cidadania no Ultramar português, Coimbra: Almedina, 2009.

54 MAMIGONIAN, Beatriz. Africanos livres, a abolição do tráfico de escravos no Brasil. São Paulo: Cia das Letras, 2017. p. 306-307. Até 1848, como esclarece Mamigonian, autora do estudo de referência sobre o tema, a maioria foi distribuída a particulares. A partir da lei de 1850, com a proibição oficial da entrega a particulares, seriam majoritariamente destinados às obras públicas de infraestrutura nas diversas províncias do pais, empreendimentos administrados diretamente pelo governo ou por concessionários. Conrad mostrou que em março de 1865 eram 720 africanos livres trabalhando, sob a responsabilidade do governo, em repartições e obras públicas pelo país. CONRAD, Robert. Neither Slave nor Free: the Emancipados of Brazil, 1818-1868. HAHR, v. 53, p. 50-70, 1973. 
Em Angola, conforme o número de navios apreendidos aumentava, nos períodos em que o governo resolvia recrudescer a vigilância - pois não foi um processo linear nem de uma curva ascendente, mas de altos e baixos -, mais libertos havia na praça. Em janeiro de 1840, o juiz de direito substituto em Luanda expunha que "tinham 910 escravos apreendidos". ${ }^{55}$ Em 1844, foi apreendido na foz do rio Dande o brigue brasileiro Caçador com "844 pretos amontoados" ${ }^{56}$ ordenou-se que dentre eles "50 casais marchassem como libertos para Moçâmedes, a fim de ali se empregarem nos trabalhos da agricultura". ${ }^{57}$

Em 1845, 92 libertos "que vieram da lancha apresada pela escuna Nimpha" foram encaminhados para as plantações de outra colônia portuguesa, a ilha de São Thomé, onde as fazendas de cacau e café seguiriam com o trabalho escravo ainda por décadas. ${ }^{58} \mathrm{~A}$ expectativa do ministério era que o fluxo de libertos fosse em direção a São Thomé e Moçâmedes, as duas apostas do momento para a produção de gêneros agrícolas coloniais. $E$ de fato foram os dois principais destinos. Um ofício do governador de Angola, em 1849, deixava o encaminhamento oficial explícito, comparando a prática com a dos ingleses:

...(fui) ordenado fazer conduzir os pretos que sucessivamente se forem libertando para S. Thomé e Príncipe, da mesma sorte que o governo britânico os faz partir da Serra Leoa para a Jamaica e outros pontos das Índias Ocidentais, ou enviar os ditos pretos para Moçâmedes a fim de ali serem distribuídos pelos respectivos colonos... ${ }^{59}$

Havia, porém, o tratado de 1842 entre Portugal e Inglaterra, e isso trazia tensões. Lord Palmerston condenou a prática do governo português, pois "como a condição de escravidão ainda existe tanto em Moçâmedes como em São Thomé, nenhuma segurança há de que os negros nominalmente emancipados, se para ali forem mandados, sejam real e praticamente livres". ${ }^{60}$

Em 1850, há uma reveladora carta do mesmo governador-geral Adrião Accacio, na qual declara que os chegados do Brasil naquela primeira leva não eram bons trabalhadores; havia sim alguns entendidos no negócio do açúcar, mas muitos eram caixeiros e artistas que não sabiam nada sobre o campo. Para resolver o impasse, tomou uma resolução: "mandei libertos e pretos, trabalhadores adequados para a agricultura". Ele esclarece ao historiador duas questões: primeiro, seguiam os envios de libertos para Moçâmedes; segundo, esvaziou

55 AHU, caixa 590. Ofício do juiz de direito substituto Ignácio Joaquim de Mello Pereira, 27 jan. 1840.

56 Conforme relato do marinheiro da corveta Urânia, Antonio Lopes de Mendonça, no jornal A Revolução de Septembro, edição do dia 7 dez. 1844.

57 SORIANO, Simão José da Luz, Revelações da minha vida e memórias de alguns fatos e homens meus contemporâneos. Lisboa: Typographia Universal, 1860. p. 561.

$58 \mathrm{AHU}$, caixa 601 . Ofício do governador de 24 out. 1845. Esse era apenas o começo do tráfico. Ao longo da década de 1850, centenas de libertos foram levados para São Thomé. Entre fevereiro de 1861 e junho de 1862, as ilhas de São Thomé receberam 1.500 africanos "com diversas designações ou estatutos". MARQUES, João P. Os sons do silêncio, 1999. p. 334.

59 AHU, caixa 615/A, ofício de Adrião Accacio da Silveira Pinto de 30 set. 1849.

$60 \mathrm{AHU}$, caixa 615/A, ofício do ministro dos Negócios Estrangeiros Lord Palmerston, de $4 \mathrm{dez}$. 1850, ao encarregado dos negócios de Portugal em Londres. Citava o tratado de 3 de julho de 1842 de Portugal com a Inglaterra, que previa o controle sobre o destino dos libertos pela comissão mista em solo não inglês, visando que não fossem escravizados e garantindo um período de aprendizado de algum ofício. 
o argumento que justificava o esforço para a colonização agrícola de Moçâmedes - vieram os brancos, mas sem os pretos, escravos e libertos, a agricultura não teria futuro. Em dezembro de 1852, o governador enviou prisioneiros feitos ao ex-Jaga de Cassange "para Moçâmedes, a fim de ali auxiliarem as plantações que agora vão progredindo". ${ }^{61}$ Atente-se que, nesse caso, não eram libertos, mas prisioneiros feitos na guerra nos sertões: eram escravos do governo.

A busca por mão de obra de baixo custo não foi, como fica claro, apanágio dos fazendeiros; os administradores públicos portugueses e brasileiros, em geral militares, nos anos 1850 e 1860, gerenciaram a circulação desses trabalhadores. Não apenas supervisionaram o processo, claro está, mas produziram o fluxo dessa mão de obra. ${ }^{62}$

Em 1857, Álvaro d'Andrea comandou uma expedição para verificar a existência de tráfico em praia próxima da foz do rio Zaire, em local chamado Cabeça de Cobra. Ali encontrou um grande barracão com capacidade para mil cativos. Álvaro d'Andrea mandou incendiar tudo, mas explicou que a apreensão dos escravos tinha sido "impossível pois os feitores não dormem e tem sempre vigias". ${ }^{63}$ Caso os escravos tivessem sido apreendidos, teriam sido, segundo as instruções recebidas, encaminhados para Ambriz, para dali serem levados a Luanda. ${ }^{64} \mathrm{O}$ governo teria então mais libertos ao seu dispor.

Fazer parte da marinha portuguesa nessa época, ser comandante de navios, era estar diretamente em contato com o comércio negreiro, conhecer com intimidade suas rotinas e estratégias. Álvaro d'Andrea foi responsável pelo apresamento de três navios negreiros. Esse era um item da ficha dos oficiais da marinha, ${ }^{65}$ os dados eventualmente colaborariam

$61 \mathrm{AHU}$, caixa 617/1. Ofício de 6 dez. 1852 do governador-geral interino Antonio Sérgio de Souza. Ele explica que, como a rainha ainda não tinha deliberado sobre mandá-los para S. Thomé, decidiu enviá-los para Moçâmedes, pois "havendo-se reconhecido por experiência que tais indivíduos não influem na pacificação daquele distrito, porquanto o rebelde Bumba tem continuado a incomodar a feira ali estabelecida, sem precisão do auxílio daqueles miseráveis", ou seja, se fugissem, não iam influir em Cassange, não seria necessária a medida mais radical de cruzarem o oceano. Como Antonio Sergio tinha acabado de sair do governo de Moçâmedes, quis favorecer a colônia. O ministério em Lisboa aprovou a decisão. A partir do decreto de 14 dez. 1854, os escravos pertencentes ao Estado colonial entrariam na condição de libertos.

62 Sá da Bandeira promulgou uma série de decretos de extinção gradual da escravatura nos anos 1850, mas a lei sujeitava os libertos à tutela pública com obrigações. O decreto de $14 \mathrm{dez}$. 1854, publicado em Angola em 1855, dizia no art. 29: "Todo o escravo que obtém por qualquer modo a sua liberdade, entra imediatamente no estado de liberto, e durante ele, é sujeito à tutela pública da Junta". Os libertos teriam a obrigação de servir por dez anos aos antigos senhores, sendo lícita a venda desses serviços, enquanto os libertos do Estado eram obrigados a sete anos de serviço. BOGGPA, 517, 15 ago. 1855. O decreto de 29 abr. 1858 previa para dali a 20 anos a liberdade dos escravos nas colônias. Depois, já na década de 1860, o decreto de 25 fev. 1869 declarava "libertos" todos os indivíduos, sem exceção, que no mencionado dia se achassem na condição de escravos. Mas não ficariam ainda livres; eram obrigados a seguir trabalhando por pequeno salário para seus antigos donos. $\mathrm{O}$ decreto de 28 abr. 1875 extinguiu a servidão dos libertos para daí a um ano, mas ficariam sob tutela pública até 29 de abril de 1878. Agora, passariam a ir para S. Thomé milhares de angolanos como "serviçais". Ver: NETO, Maria da Conceição. De escravos a serviçais, de serviçais a contratados: omissões, percepções e equívocos na história do trabalho africano na Angola colonial. Cadernos de Estudos Africanos, n. 33, p. 107-129, 2017.

63 AHU, caixa 623/1, ofício do comandante Álvaro d'Andrea escrito a bordo da escuna Cabo Verde para o comandante da Estação Naval em Luanda, 14 mar. 1857.

64 AHU, caixa 623/1, ofício confidencial do governador-geral de Angola para o chefe da Estação Naval com instruções para o comandante da escuna Cabo Verde, 7 mar. 1857.

65 As informações nas fichas dos oficiais que os comandantes dos navios tinham que preencher dão uma dimensão das expectativas da instituição sobre seus quadros: Louvores que tem tido/Castigos que sofreu/ Prêmios, condecorações/Quantos cruzeiros contra o tráfico da escravatura e as presas que se fizeram/Se é ativo e capaz de serviço violento, ou moderado, ou se é relaxado e não cuida de seus deveres/Se são 
em uma promoção. Havia também incentivos pecuniários. ${ }^{66}$

Ao ler a correspondência administrativa, os boletins de governo, as memórias escritas por militares, paira um silêncio sobre as contradições ali experimentadas por aqueles homens. Por vezes, alguém rompia o silêncio da hipocrisia. Há um minucioso relato manuscrito do médico oficial da marinha Antonio Justino de Faria Leal que acompanhou a expedição de ocupação do porto de Ambriz, ordenada por Sá da Bandeira em 1855. As condições eram precárias, os homens andavam e lutavam sob o sol quente e quando descansavam era em abafadas e úmidas barracas de lona; o médico não entendia por que não imitavam os "peritos pretos que construíam frescas barracas de ramos de árvores." Em junho, a força portuguesa da guarnição do Ambriz era de 1.000 homens, sendo "500 das companhias móveis dos presídios" (as guarnições das fortalezas não tinham apenas atuação local). Para o médico, "os negros livres do Ambriz toleram o nosso domínio porque têm medo da artilharia e de cavalos, mas não reconhecem ainda o direito dele". Antonio Justino observou também que "a jovem colônia de Moçâmedes" tinha sido fundamental para a sobrevivência da expedição, enviando bois vivos, carne seca e peixe salgado.

Também em Ambriz, o trabalho dos libertos foi utilizado. Antonio Justino diz que ali havia entre 120 e 130 libertos, homens e mulheres que faziam todos os tipos de serviços, sobretudo os públicos: "prestavam bons serviços trabalhando na vala, na calçada, nas construções, acarretando madeira e lenha do mato, água do rio, servindo no hospital, na botica etc". Busca definir essa condição, não porque seu interlocutor não soubesse, afinal o relatório era dirigido ao dr. Jacques Nicolau de Salis, físico-mor da província de Angola, mas porque desejava exprimir sua crítica:

os libertos são negros, a quem o governo promete a liberdade dentro de um tempo marcado, obrigando-os entretanto a trabalhar mediante uma parca ração e uma tanga d'algodão para se cobrirem. Quando o liberto foge, ou não quer trabalhar, leva açoites com um azorrague de cinco pernas e, entretanto, não se chama escravo, é liberto. Mas o visconde d'Almeida Garret imaginou a palavra libertinagem para indicar oficialmente o estado do liberto, por Ihe não ser aplicável a palavra liberdade. ${ }^{67}$

Terminou afirmando que a mortalidade entre os libertos era grande, "como é fácil de compreender". Esse relato mostra um olhar crítico que explicitava as contradições do processo, por alguém que estava em Angola no período. Mesmo ao considerar que "os pretos não admitiam ainda o direito da presença portuguesa" (supondo então que acabariam por admitir a legitimidade desse direito), deu livre arbítrio aos povos locais que, avaliando as circunstâncias, intimidados pelas armas, toleravam os portugueses. Foi dos únicos relatos que recusou a hipocrisia: o médico

decentes as companhias que frequenta e qual a conduta nos portos etc. Arquivo Histórico da Marinha (Lisboa), caixa 720 , ficha de 9 jul. 1860.

66 Arquivo Histórico da Marinha (Lisboa), caixa 720, ofício de 13 fev. 1864, sobre o que ele deveria receber pelo apresamento da barca Velha Anita.

67 Arquivo Histórico da Marinha, Ultramar, Angola, caixa 1339-A. Relatório de Antonio J. de F. Leal, cirurgião ao dr. Jacques Nicolau de Salis, físico-mor da província de Angola, 15 dez. 1857. 
não considerava que o trabalho fosse civilizatório para os libertos. Descreveu os serviços que faziam, trabalhavam sobretudo para o governo e sofriam violência.

Outro fator importante para ser examinado com relação aos expedientes lançados nesse período buscando o controle do trabalho ou, para dizer nos termos da época, buscando o 'esforço civilizatório', eram as políticas fiscais. Para isso, vale observar uma outra região em Angola nessa época. Em 1857, foi criado o distrito de Golungo Alto, com jurisdição ampla sobre região importante do interior no fluxo com Cassange. Era uma região de crescimento econômico em Angola naqueles anos e contava com a maior concentração de libertos: em 1863 havia o impressionante número de 21.182 registrados. ${ }^{68}$

A mais espinhosa tarefa do governador de Golungo Alto foi colocar em prática a nova legislação ${ }^{69}$ que proibia o uso do trabalho forçado dos carregadores e, ao mesmo tempo, querendo garantir rendimentos ao governo e, sobretudo, forçar os indígenas ao trabalho, mandava aumentar o dízimo. A expectativa era que sendo os "pretos avessos ao trabalho",70 era preciso que tivessem a necessidade de trabalhar; ao aumentarem os dízimos, eles seriam empurrados ao mercado de trabalho caso contrário seriam presos. ${ }^{71} \mathrm{E}$, de quebra, com o crescimento dos impostos, ampliariam as rendas do Estado.

No entanto, o governador lamentava preocupado, pois o fluxo do comércio entre Luanda e Golungo Alto estava alterado, os carregadores levavam o tempo que queriam e ainda "roubaram a pólvora, completaram com terra." Observou, ainda, que bastou verem-se "livres do chicote e outros rigores" para praticarem "os maiores abusos". ${ }^{72}$ Sabotavam, recusavam-se a trabalhar da maneira que os portugueses queriam, resistiam. O governador explicitava a violência cotidiana no controle do trabalho, deixando à imaginação do leitor o que eram os 'outros rigores'. As novas leis proibiam o uso do "vexame dos castigos", mas o governador-geral autorizou o uso de outra violenta arma de "reconhecida eficácia" para buscar o controle do trabalho: a expatriação. ${ }^{73}$

Os oficiais do exército português, que eram chefes de distritos em Angola nas décadas de 1850 e 1860, ao mesmo tempo em que viam suas funções serem alteradas

68 FERREIRA, Roquinaldo. Escravidão e revoltas de escravos em Angola, Afro-Ásia, n. 21-22, p. 20, $1998-1999$. O autor tirou os dados do AHU, pasta 34, "Nota dos números de libertos registrados..."

69 Coleção da Legislação Portuguesa, Livro de 1856. Decreto de 3 de nov. de 1856, abolição do serviço forçado dos carregadores e aumento do dízimo. p. 503.

70 AHU, caixa 623/1. Relatório do governador de Golungo Alto, tenente-coronel Antonio J. de Castro, 1 out. 1857.

71 AHU, caixa 623/1, ofício do secretário-geral, 15 dez. 1857: "Pondera Sua Excelência que a incúria dos pretos há de ser vencida, sendo para isso um dos meios próprios, o mesmo aumento do imposto."

72 AHU, caixa 623/1, ofício do governador de Golungo Alto para o governador-geral de Angola, 14 nov. 1857. Dizia que proceder ali conforme a lei era muito difícil, pois era necessário processo, provas testemunhais, e os roubos eram feitos no mato. Ele via uma guerra entre pretos e brancos.

73 O governador-geral mandou que o governador de Golungo Alto identificasse os culpados e os mandasse para Luanda, de lá seriam enviados para outro ponto da província, "na impossibilidade da aplicação dos meios legais", inibiria essas atitudes "pela repugnância sabida que têm os pretos à expatriação". AHU, caixa 623.1, ofício de 23 nov. 1857. Ao invés do governador-geral assumir o papel "civilizatório" propagando o direito, autorizava o governo local a agir despoticamente. O procedimento não foi criticado pelo ministério em Lisboa. Sobre o processo nada linear da aplicação da justiça portuguesa no ultramar, ver o excelente estudo de: SILVA, Cristina Nogueira da. A construção jurídica dos territórios ultramarinos portugueses no século XIX. Lisboa: ICS, 2017. 
(procurava-se coibir os ganhos com os carregadores e com o comércio de mercadorias, inclusive escravos, atrativos para o exercício desses postos nos sertões), eram convocados a incentivar a agricultura e cuidar da administração elaborando tabelas, estatísticas, relatórios. Mas assumiam também outros papéis no empreendimento colonizador "moderno". Capturar escravos fugidos era um desses papéis, como atestam as várias cartas de agradecimento de proprietários publicadas no boletim do governo. ${ }^{74}$ Ou seja, o governo português atuava no esforço de manter a escravidão ativa em Angola.

A administração pública em Angola, buscando fontes de recursos, também negociava escravos, como podemos observar ainda em 1851:

.... o major Francisco de Salles Ferreira, comandante da expedição mandada àquele sertão, chegou a Luanda acompanhando 359 prisioneiros, sendo 319 escravos e 40 indivíduos livres, que convém sejam mandados para as ilhas de São Thomé e Príncipe, como eu já pedi... Tenho mandado vender em praça pública os escravos capturados para assim se satisfazerem as despezas da expedição. ${ }^{75}$

Ou seja, os 40 indivíduos categorizados como 'livres' foram para São Thomé e os outros 319 foram vendidos em leilão como escravos. Em 1854, havia 461 escravos em Moçâmedes e em 1864 seriam 2.073, sinalizando para o aumento da produção, o ativo funcionamento de redes de tráfico, já que os escravos não vinham da região (pois as fugas seriam certas e os sobas locais só admitiam que seus 'filhos' trabalhassem se quisessem e mediante pagamento). Vê-se a força da escravidão para além do trabalho dos libertos (eram 291 em 1863). ${ }^{76}$ Como já ressaltou Aida Freudenthal, "as estruturas de comercialização herdadas da época do tráfico atlântico continuaram a assegurar a aquisição de escravos, mantendo vivos os circuitos internos." 77

Refletindo sobre os impasses envolvidos no governo colonial do período, o governador-geral de Angola José R. Coelho do Amaral escrevia para Sá da Bandeira sobre a conveniência

74 Por exemplo, no BOGGPA, n. 513, carta de 25 jun. 1855, falando da fuga de escravos das feitorias de urzella no sul (provavelmente em Moçâmedes), agradecendo ao tenente Francisco G. Cabral e Mello, chefe de Quilengues: "na pesquisa de os apanhar, se tem portado com tal sagacidade que raros são os escravos que tem deixado de ser capturados".

75 AHU, caixa 615/A, ofício do governador-geral Adrião Accacio da Silveira Pinto, 25 jun. 1851.

76 Pelo decreto de 14 dez. 1854, "artigo 7: Todo o escravo importado por terra em domínios portugueses depois da publicação... fica considerado na condição de liberto, com a obrigação, porém, de servir o senhor por tempo de dez anos". O governador disse, em relatório de 1864, que havia mais de 2.000 escravos em Moçamedes. Para o Conselho Ultramarino era "o nosso direito e o nosso dever" obrigar ao trabalho aqueles povos ainda na infância. DIAS, Jill e ALEXANDRE, Valentin, O Império Africano, 1825-1890, Série Nova História da Expansão Portuguesa, Lisboa, Editorial Estampa, p. 86, 1998. A historiadora esclarece ainda que ocorria uma aproximação dos interesses da praça mercantil de Lisboa com os da praça de Luanda, as exportações da praça de Lisboa cresceram de 435 contos em 1848 para 1.051 contos em 1856. Roquinaldo Ferreira fala do crescimento das formas de trabalho forçado na economia de Angola no período. Escravidão e revoltas de escravos em Angola. Afro-Ásia, n. 21-22, p. 20, 1998-1999. Em 1866, segundo relatório do governador-geral Calheiro e Menezes, o maior produtor de café no Cazengo perdeu 461 escravos por fuga. Note-se o tamanho da força de trabalho desse fazendeiro, compatível com as maiores fazendas de café no Brasil. Sobre o grande volume de fugas de escravos em Angola na segunda metade do XIX, ver também: CURTO, José C. Resistência à escravidão na África: o caso dos escravos fugitivos recapturados em Angola, 18461876. Afro-Ásia, n. 33, p. 67-86, 2005.

77 FREUDENTHAL, Arimos e fazendas, p. 225. 
da criação de novas vilas; eram, ao mesmo tempo "instrumento de civilização", da elevação moral dos povos, e de potencial conflito; era preciso saber quando e onde era melhor ter câmaras municipais ou apenas chefes militares. ${ }^{78}$ Dizia isso pensando em Moçâmedes onde houve conflito entre a Câmara e o governador militar local (Fernando da Costa Leal). Acabou por avaliar positivamente a institucionalização e a criação de mais uma vila, mas seria um processo em etapas, primeiro uma comissão municipal, depois a Câmara eleita, ${ }^{79}$ assim como o trabalho forçado seria uma etapa entre a escravidão e o trabalho livre. Opinava também pela necessidade de começar a eliminar alguns sobas, "intermediários que bloqueiam a civilização e o progresso dos indígenas". ${ }^{80}$ Ao mesmo tempo, os filhos dos régulos mais notáveis, segundo portaria de Sá da Bandeira de novembro de 1856, deveriam ser incentivados a ir para Luanda estudar, "ação civilizadora concretamente centrada na língua e na religião (...) civilizar era, nesta fase da política colonial portuguesa (e europeia), europeizar". ${ }^{81}$ Civilizar era também o discurso para justificar o trabalho forçado, que, por sua vez, era visto como uma etapa do aprendizado dos "novos tempos".

A experiência das feitorias representava já o passado no projeto de lei de 1856, quando o Conselho Ultramarino pedia um crédito de 400 contos para o estabelecimento de colônias,

mas verdadeiras colônias, e muito distintas das feitorias destinadas ao abominável tráfico (...), as instituições de ensino público, a lgreja, e ainda a ação paternal e imparcial da autoridade que administrar a colônia; tudo isto encaminhará os negros para a civilização. ${ }^{82}$

\section{Conflitos e armas: a permanente resistência}

POR FIM, é preciso ressaltar a dimensão militar, muitas vezes subestimada. O esforço colonizador em Angola nessas décadas foi também uma mobilização pelas armas, foram muitas as batalhas. Guerras que explicitam a perseverança da resistência.

Em Moçâmedes, para além do destacamento do forte S. Fernando - em 1849 o efetivo era de 100 homens (brancos, degredados), mas em 1858 já eram $500^{83}$ - houve a presença,

78 AHU, caixa 622/2, ofício do governador-geral de Angola, 30 dez. 1856.

79 AHU, caixa 622/2, ofício do governador-geral, 30 dez. 1856. Portaria de 28 mar. 1857, mandando o governador de Angola nomear uma comissão municipal para Cazengo. Sobre a medida para criar uma etapa intermediária, cf. NOGUEIRA, A construção jurídica, p. 126 e 127.

80 AHU, caixa 622/2, ofício do governador, 30 dez. 1856. Sobre os sobas: "tenho já procurado ir acabando com os sobas, sem atacar muito de frente os hábitos dos indígenas (...). Havia conveniência em se fazer uma nova divisão dos distritos, suprimindo as dos sobados, e dando (...) denominações portuguesas, de terras do reino, patronímicas, ou alusivas a acontecimentos notáveis de história do país. São tudo meios de civilização".

81 SILVA, Cristina N. da, Constitucionalismo e império, a cidadania no Ultramar português. Coimbra: Almedina, 2009. p. 304.

82 Projeto de lei sobre o estabelecimento de colônias nas províncias de Angola e Moçambique, 11 abr. 1856 , Anais do Conselho Ultramarino, parte oficial, ser. II, p. 77. Assinaram o projeto: Sá da Bandeira, Ferreira Pestana, Pereira de Mello, Arouca, Oliveira Lima, Silva Guardado. Grifo meu.

83 ARANHA, Brito. Mossamedes. In: Memórias histórico-estatisticas de algumas vilas e povoações de Portugal. Lisboa: Livraria A. M. Pereira, 1871. p. 245. É expressivo do que significava Moçamedes que o autor tenha publicado em 1871 esse livro (tão ao gosto do tempo, divulgando estatísticas) e inclua entre as vilas de Portugal justamente uma da África, que não tinha 20 anos de existência. As outras eram: Povoa do Varzim, Louzã, Marinha Grande, Peso da Regoa e Vista Alegre. 
sobretudo nos primeiros anos, de um navio de guerra ancorado na baía. Em Angola, em Moçâmedes, nos sertões onde se iam instalando fortes, os ataques e as batalhas eram uma realidade constante; os soldados, as armas, os canhões, não representavam presença figurativa ou simbólica.

Cada presídio tinha seu destacamento, maior ou menor a depender da importância estratégica, mas a cada conflito Luanda enviava reforços nos navios de guerra, se fossem pontos do litoral. Para o interior, eram as gentes dos sobas que fariam a diferença. Luanda tinha seus Corpos de Linha, com soldados degradados e oficiais. ${ }^{84}$ Alguns com especial valor, pois dominavam o estilo de "guerra preta", conheciam o território e os costumes dos povos locais.

Se em 1850 o governador de Moçâmedes junto com Bernardino e outros tinham empreendido uma expedição considerada exitosa aos Gambos, essa segurança revelou-se instável. Com o crescimento do comércio, o governador Fernando da Costa Leal quis ali deixar uma pequena força regular, mas o novo soba não permitiu tal ocupação. O governador subiu então ao planalto pessoalmente com 80 soldados e quatro peças de artilharia até a Huila, onde começou a construção de uma fortaleza, seguindo depois para os Gambos, mas ali ficou em situação delicada. Preocupado, mandou Bernardino Figueiredo procurar ajuda em Quilengues. ${ }^{85} \mathrm{O}$ soba Binga cortou as comunicações dele com a Huila, e Costa Leal ficou cercado por 8.000 homens. Após dois meses de tensão, o governador não teve outra escolha senão recuar para a Huila, perdendo essa pretensão expansionista.

Bernardino de Abreu tardou, mas conseguiu reunir reforços. A "guerra preta" viria com 50.000 homens, em "poderosa guerra como ainda não viu o sul da província". Perspicaz que era, sabia que viriam outras iguais ou maiores no futuro. Em setembro de 1856, a ofensiva chegava aos Gambos. Diante de tão numerosa tropa, o soba Binga fugiu com o seu povo. Ao final do ano, Binga retornou e avaliou como melhor alternativa parar a guerra e aceitar a presença portuguesa. Em março de 1857, os Gambos foram reconstituídos como conselho. ${ }^{86}$

Foi só depois dessa ofensiva que o governo de Moçâmedes conseguiu impor ao soba uma contribuição, pois até então não "pagavam coisa alguma", ${ }^{87}$ embora o primeiro tratado tenha sido feito em 1850. Naquela ocasião, na cerimônia para o acordo, o soba Hamba Hakitura Nambalo Quiquima declarou: "eu sou o primeiro dos bichos, capaz de engolir a todos os outros bichos e a todos os sobas; mas sou amigo dos brancos que são meus filhos", ${ }^{88}$ ou seja, agiu como um chefe que protegia e não que precisava de proteção. Se algum tipo de pagamento

84 Os diversos governadores em Angola, entre 1838 e 1860, pediam pelo envio regular de degredados para o aumento dos destacamentos, avisavam que o ideal seria que não se demorassem nas cadeias do reino, adquirindo "piores hábitos". AHU, caixa 587, 19 mar. 1839. Cada novo ponto ocupado representava necessidade de mais homens e armas, necessidade que em grande medida foi atendida pela circulação dos mais desvalidos. Havia também fugas. Em cada novo tratado de vassalagem com os sobas, uma cláusula sempre presente era que não abrigassem desertores ou escravos fugidos.

85 Bernardino contou, em ofício de 6 set. 1856, que em Quilengues teve o apoio do chefe cap. Francisco Godinho, que com o chefe de Caconda reuniram a "poderosa guerra". AHU, caixa 622/2.

86 PELISSIER, op. cit., p.182-184.

87 AHU, caixa 622/2, carta de Bernardino F.F. Abreu e Castro, 6 set. 1856.

88 AHU, caixa 615/2, memória da expedição aos Gambos por Bernardino F. de Abreu, 30 dez. 1850. 
era um dos pressupostos para os tratados, na prática dependia da correlação de forças. Havia um jogo de poder, mesmo que desigual, mesmo que muitos tenham sido expulsos das terras. Expulsos, mas não escravizados. Outros tantos decidiram pelo enfrentamento armado.

Nesse meio tempo, Fernando da Costa Leal terminou a fortaleza na Huila, local considerado estratégico e fértil. O governador ficou animado: "a colonização deste lindo país é a que se deve seguir a Moçâmedes". As obras foram feitas com "os braços da Companhia de Linha do distrito, motivo porque se fez muito economicamente". ${ }^{89}$ Os engajados não eram necessários só para a guerra, mas também para construírem estradas, edifícios, fortalezas. Empenhado pela colonização da Huila, o governador-geral de Angola enviou de Luanda 40 libertos para "os trabalhos agrícolas". ${ }^{90}$

Mas o sossego foi breve. Em outubro de 1857, houve um forte ataque por mais de 6.000 nanos na Huila. Fernando da Costa Leal, sabendo da conjuntura tensa, tinha mandado um reforço para lá com 27 praças, o que subia "a força para 101 baionetas, mais que suficientes para, acobertos com a fortificação e com o jogo de artilharia, repelir qualquer assalto". ${ }^{91} \mathrm{De}$ fato, os portugueses conseguiram articular a defesa, mas houve muitos mortos. Candeias da Silva fala em "mais de 100 homens entre os atacantes", enquanto nos defensores houve feridos. ${ }^{92}$

Pouco menos de um ano depois, em setembro de 1858, era realizado de Lisboa o embarque da "1a Companhia do Batalhão de Caçadores que como Colônia Militar se vai estabelecer na Huila". ${ }^{93}$ Era, nesse movimento de expansão, a primeira com essa denominação. ${ }^{94}$ lam 104 soldados, mais "50 mulheres e 44 filhos". Pouco tempo depois, em 1861 , seria organizada a de Capangombe, considerada mais exitosa do que a da Huila. ${ }^{95}$

A colônia militar da Huila instalou-se e já teve o papel de recuperar, em maio de 1859, os Gambos, pois as tropas portuguesas tinham sido novamente expulsas em agosto de 1858 . Era um movimento de avanços e recuos. Não foi exatamente agrícola e pacífica a vida dos soldados na região, mas a maior batalha ainda estava por vir. No ano seguinte, em 1860, uma poderosa ofensiva nano de 30.000 homens venceria a Huila (vitória facilitada por parte do

89 Nessa carta, sugeria a colonização militar de preferência à civil e falava do novo estabelecimento dos ingleses na baía de Wallfish, ao sul de Moçâmedes, tocando no tema tão caro da concorrência colonial. Huila ajudaria como barreira aos interesses dos ingleses. AHU, caixa 623/2, 30 jan. 1857.

90 Ofício de 12 set.1857 do governador ao ministro, citado por: SILVA, Candeias da. Subsídios..., p. 42.

91 O governador, quando fala do ataque, diz que também o engenho de José Leite de Albuquerque, no Bumbo, tinha sido atacado, mas como ele tinha para defesa de seu estabelecimento "um destacamento de tropa e duas peças de artilharia, pudera se defender". AHU, caixa 623, 1 nov. 1857. O governo fortificava os engenhos, destinava soldados e canhões.

92 SILVA, op. cit., p. 44.

93 O decreto para organizar a colônia era de julho de 1857. Os trâmites foram rápidos.

94 No começo de 1859, Sá da Bandeira mandou organizar uma colônia militar para estabelecer-se no Tete, em Moçambique. Ver: OLIVEIRA, Delfim José de. Diário da viagem da colônia militar de Lisboa a Tete, 18591860. Centro de Estudos Africanos da Universidade do Porto. Porto: Edições Húmus, 2014. p. 19.

95 O objetivo era proteger Moçâmedes e garantir os fluxos comerciais com o interior. Foram novamente pouco mais de 100 homens, degredados, soldados recrutados e luso-brasileiros, mais mulheres e filhos. Os colonos enraizaram-se na região que era fértil, ambicionada para o café. Em 1866, já havia diversas fazendas de café instaladas, uma inclusive do Brochado, o sertanista português que antes atuava nos Gambos e negociava escravos e tecidos. Ver: Relatório do governador Leal de 1866 e do governador-geral de Angola para 1861. ARANHA. Memórias histórico-estatísticas, 1871. p. 247/248. 
destacamento estar nos Gambos, e outra parte no Humbe), o chefe comandante português Silva foi decapitado. Na sequência, os nanos desceram para Moçâmedes, atacaram e queimaram diversos engenhos pelo caminho. $\mathrm{O}$ gado foi levado, os moradores que conseguiram fugir esconderam-se nos navios ancorados na baía. Bernardino e outros foram feitos prisioneiros. Por isso foi rápida a decisão de uma nova colônia militar em 1861, em Capangombe.

Nesse movimento de interiorização da ocupação portuguesa para o estabelecimento de novas rotas comerciais, assim como para estimular a produção agrícola, a dimensão militar era fundamental. Eram frequentes as investidas dos povos locais, era difícil vencer em tantas frentes, muitas batalhas foram perdidas pelos portugueses. Como tantos autores já ressaltaram, e fica claro na documentação, a aliança com o régulo local, os sobas, era vital, era a condição da presença portuguesa, mas não era a garantia dessa presença. Um novo soba podia não reconhecer a aliança feita pelo seu antecessor, como nos Gambos, por exemplo; ou a mudança nas leis portuguesas, como a nova cobrança dos dízimos, podia afastar aliados, provocar migrações. Pélissier considera que, nos anos 1850, as guarnições sairiam de suas fortalezas, pondo-se em movimento e sendo muito agressivas, "na medida das suas tradições". ${ }^{96}$ Ao final dos anos 1870, porém, os portugueses precisaram recuar e abandonar muitas das conquistas efetuadas nesse período. $O$ fato de parte das conquistas não ter permanecido eclipsou o estudo das ações empreendidas pelos portugueses nas décadas de 1840 e 1850, e, sobretudo, esvaziou a dimensão da forte resistência local e da disputa.

Em 1856, Bernardino ficou ausente de Moçâmedes por oito meses, buscando resolver as tensões no interior. Ao voltar, em dezembro, encontrou a sua fazenda queimada, não explica por quem, nem explicita possíveis motivos, só conta que perdeu "todos os laboratórios". Em carta a Sá da Bandeira, junto com a declaração que ia tentar vender o que restara, dizia do crescimento da produção de algodão, do qual enviava novas amostras, falava do progresso de Moçâmedes mesmo com a crise nos sertões, graças aos baleeiros americanos que paravam no porto da vila para se abastecer - tinham naquele ano chegado 30 navios e movimentado a economia local. Pedia também cópia da medalha que ganhara na Exposição Universal, pois se sentia "compensado apesar de tantos desgostos". ${ }^{77}$ Não seria fácil reconstruir a fazenda. Mal reerguera tudo, veio o devastador ataque dos nanos em 1860. Dessa vez não fugiria assustado com a violência, como saiu do Recife, 11 anos antes.

Bernardino publicou um texto em 1857 opinando pela abolição gradual da escravidão. No texto, postulava ser contra a divisão entre libertos e escravos. A escravidão pelos europeus, não a praticada pelos chefes locais, era, para ele, o único meio de transformar a realidade africana; na sua visão, a experiência do trabalho "civilizaria" os indígenas na África. Orgulhava-se que na sua fazenda vinha formando homens diligentes, com novas ambições. ${ }^{98}$

96 PELISSIER, op. cit., p. 89.

97 AHU, caixa 622/2, carta de Bernardino Freire de Figueiredo para Sá da Bandeira, 14 dez. 1856,

98 Parecer de Bernardino de F. Abreu e Castro sobre o fim da escravidão e do tráfico, publicado no BOGGPA, 
Ele diz que não enfrentava fugas, ${ }^{99}$ ao contrário de muitos em Moçâmedes que abusavam da violência. ${ }^{100} \mathrm{Em}$ seu engenho, purificava-se da luta política produzindo aguardente com o suor dos escravos e colecionava medalhas na Exposição Universal de Londres de 1856, de 1862, e depois na Exposição Internacional do Porto de 1865 "pela qualidade do produto". A bandeira do progresso tudo justificava, e ainda era apartidária (um pecado ter partido àquela altura). Além do reconhecimento, por assim dizer, científico, em diálogo com os novos tempos, Bernardino foi também agraciado com a mercê de cavaleiro da Ordem de Cristo em 1866.

Manteve-se na crença da vitória do projeto civilizatório colonial, sentia-se confortável como senhor escravista, cioso do papel histórico de fundador da colonização agrícola militar em Moçâmedes. Mantinha correspondência direta com o ministro e aparecia nos jornais. Abandonara a luta política, por vezes reclamava da "inveja e perseguições" que sofria. Estava distante o tempo de professor de História no Recife, ou de combatente aguerrido pela causa absolutista em Portugal.

Recebido em: 03/04/2020

Aprovado em: 24/06/2020

n. 611, jun. 1857. Enquanto a escravidão civilizaria a África, o tráfico tudo aniquilava.

99 Jill Dias fala nas constantes fugas de escravos que os fazendeiros de Moçâmedes enfrentavam. DIAS, Jill. Nova história da expansão, p. 458. Em janeiro de 1860, houve a fuga de 100 escravos de uma feitoria de Moçâmedes para o sertão. Produtores de urzela encaminharam uma "manifestação antitráfico" para o ministério. Cada um tinha mais de uma centena de escravos na apanha de urzela, nas pescarias e no plantio de algodão, as principais atividades econômicas de Moçâmedes na época. FERREIRA, R. Escravidão e revoltas, Afro-Ásia, n. 21-22, p. 39. Sobre a urzella, nesse período, ver: WISSEMBACH, Maria Cristina. As feitorias de urzela e o tráfico de escravos: George Tams, José Ribeiro dos Santos e os negócios da África Centro-Ocidental na década de 1840, Afro-Ásia, n. 43, p. 43-90, 2011.

100 No relatório de Costa Leal de 1864 do governo de Moçâmedes, lê-se sobre a violência praticada por senhores e feitores dos escravos e libertos. O juiz de direito chegara naquele ano (antes havia apenas o juiz ordinário, sempre "dependente dos habitantes") e já instaurara processos e prendera indivíduos como "João de Sá, pelo crime de espancamento e tortura numa preta sua escrava; José Gomes de Carvalho, pelo crime de homicídio de dois negros, resultado de espancamento". Relatório do governador de Moçâmedes, Fernando da Costa Leal, 30 set. 1864 apud SOUSA, Rosa, op. cit., anexo. 